\title{
MEDICAL EXPERTS AND THE GHOST OF GALILEO
}

\author{
Peter Huber* \\ I

\section{INTRODUCTION}

The astronomer would prefer not to be confused with the astrologist, nor the chemist with the alchemist. Take the serious sciences of allergy and immunology, brush away the detail and rigor, and you have the junk science of clinical ecology. Do the same for pharmacology, and you arrive at homeopathy. The orthopedic surgeon is paired with the osteopath, the physical therapist with the chiropractor, the mathematician with the numerologist and the cabalist. Serious scientists searching for extraterrestrial intelligence "keep light-years of distance between themselves and believers in unidentified flying objects." 1 Out on the fringe of surgery, one finds charlatans aplenty, who claim to operate with rusty knives but no anesthesia, who prey on cancer patients so desperate they will believe a palmed chicken liver is really a human tumor. ${ }^{2}$

The early commentary on junk science consists of color, humor, and aspersion in about equal measures. In 1899, David Starr Jordan, a past president of Stanford University, renowned expert on fish, and prolific writer, coined the term "sciosophy"-from the Greek "shadow wisdom"-to denote the "systematized ignorance" of the pseudo-scientist. ${ }^{3}$ Jordan followed with a rambling book, The Higher Foolishness, published in 1927, which describes some choice junk science of that era. At about the same time, David W. Hering published his more readable and even-handed Foibles and Fallacies of Science, ${ }^{4}$ which traces out histories of various pseudosciences, from astrology to alchemy to perpetual motion, and their "unexpected, even startling

Copyright $\odot 1991$ by Law and Contemporary Problems

This article is adapted from Peter W. Huber, Galileo's Revenge: Junk Science in the Courtroom (Basic Books, 1991).

* Senior Fellow, Manhattan Institute for Policy Research; Of Counsel, Mayer Brown \& Platt.

I am. extremely grateful for the excellent and tireless help I have received from my research assistant, librarian, and editor-at-large, Tammy Giles.

1. William J. Broad, Hunt for Aliens in Space: The Next Generation, NY Times C1 col 5 (Feb 6, 1990).

2. See, for example, John G. Fuller, Arigo: Surgeon of the Rusty Knife (Crowell, 1974), reviewed by Martin Gardner, "Uir" and "Arigo," NY Rev Books, May 16, 1974, reprinted (with ensuing correspondence) in Martin Gardner, Science: Good, Bad and Bogus 275 (Prometheus Books, 1989).

3. See David Starr Jordan, The Higher Foolishness: With Hints as to the Care E Culture of Aristocracy 15 (Bobbs-Merrill, 1927); see also David Starr Jordon, Brief Sketches on Ecclesiasticism. Science $\mathcal{E}^{3}$ the Unfathomed Universe 15 (Bobbs-Merrill, 1927).

4. David W. Hering, Foibles and Fallacies of Science (D. Van Nostrand, 1924). 
resemblance" to modern-day fallacies. ${ }^{5}$ Hering also notes how real scientific advance invariably spawns junk science diversion: "No sooner does a new fact or a new discovery appear in science than it is exploited in fakes." 6

Other books of similar ilk seem to follow every few decades or so. In 1936, Joseph Jastrow edited a collection of papers entitled The Story of Human Error.? In 1952, Martin Gardner published his more lighthearted Fads $E$ Fallacies in the Name of Science. ${ }^{8}$ Since then, general articles on the subject have appeared sporadically, usually precipitated by such non-events as the discovery of cold fusion in early 1989.9 Scientific American periodically runs columns such as "Death Watch," an update on "dubious but enduring" pseudo-scientific theories. ${ }^{10}$

The illustrations are always the easy part, especially when drawn from history long departed and debunked. Far more difficult has been articulating general principles for how to distinguish between legitimate science and quackery. Jordan emphasized empirical evidence:

Sciosophy is not derived from tested and verified human experience, because life is short and humanity demands quick returns. ... Its processes are instantaneous and intuitional, while all sciertific tests on the contrary are slow and laborious. It is indeed idle to wait for these when tradition, analogy, impulse, imagination are all at hand pointing straight to truth or at least indicating that one conception is as good as another, if not better. ${ }^{11}$

For the sciosophist "truth exists only in terms of human experience. . . $[\mathrm{O}]$ ne thing is as real as another if as clearly apprehended." 12

Jastrow could not do much better. Anything "subjective," anything reflecting "error" is suspect. The Church, governments, "general credulity," even the constraints of conservatism and complacency 13 within the scientific disciplines themselves, are all sources of error. "Primitive" thinking, or the "prescientific mentality," begets error. ${ }^{14}$

\footnotetext{
5. Id at $1-2$.

6. Id at 1 . In the Name of Science, appeared in 1952. 22 (June 1990).

11. Jordan. The Higher Foolishness at 15-16 (cited in note 3).

12. Id at 40-41.

13. Howard Haggard writes that
}

7. Joseph Jastrow, ed, The Story of Human Error (D. Appleton-Century, 1936).

8. Martin Gardner, Fads \& Fallacies in the Name of Science (Dover, 1957). An earlier edition, titled 1989).

9. Robert P. Crease \& N. P. Samios, Cold Fusion Confusion, NY Times Magazine 34 (Sept 24,

10. John Horgan, Death Watch; Updates on Four Dubious but Enduring Theories, Scientific American

[t]here is a far more serious error of medicine than mere ignorance. It is one which is ingrained in human behavior and which has marked beyond all others in the history of medicine. It is the error of complacency, the continual tendency to accept what is known as the fina, to cease the search for knowledge and to crystallize both fact and fallacy into dogma.

See Howard W. Haggard, Errors in Medicine, in Jastrow, ed, The Story of Human Error at 390 (cited in note 7).

14. Jastrow, The Story of Human Error at 6 (cited in note 7). 
In a later book, Science: Good, Bad and Bogus, ${ }^{15}$ Gardner finally tackles the line-drawing problem head on, and dispatches it swiftly:

No one can define exactly what is meant by such words as pseudoscience, crank, and crackpot. The reason is simple. There is no exact way to define anything outside pure mathematics and logic, and even there some basic terms have extremely shaggy edges. It does not follow that colloquial terms assigned to portions of continua are not useful. ... [1] f we did not have words for extrema, such as black and white, night and day, hot and cold, we could not talk at all. ${ }^{16}$

There is also, of course, a much more solemn philosophical literature on science and its opposite. Paul Thagard, ${ }^{17}$ for example, emphasizes the difference between "resemblance thinking" (a frequent source of error when inferring causal connection ${ }^{18}$ ), "correlation thinking" (the basis of true science), and a bastard mix of the two, on which pseudoscience often rests.

Robert Weyant has proposed a somewhat more helpful trichotomy, separating science, protoscience, and nonscience. Nonscience can be "shown formally ... to be incompatible with criteria generally accepted, at the time, as being necessary for demarcation as a science." 19 A real science, by contrast, will "meet such criteria. . . . [It is] testable, in principle, through sensory experience."20 Weyant thus starts with what the legal scholar will recognize as the philosopher's version of the Frye rule. ${ }^{21}$ This version, like Frye's, begs familiar questions about just who and how many are anointed to do the "general accepting." Stated another way, how do we deal with what Gardner calls the Hermit Scientist, the Einstein (or at least the Einstein of myth) who toils for years in splendid isolation, then emerges with claims that may transform the scientific world?

Weyant's protoscience is a "non-science-claiming-to-be-a-science," an aspirant not yet admitted to the club. Its weakness may lie entirely in its youth. But it is presented in terms that can be reformulated and formally tested according to generally accepted scientific criteria. ${ }^{22}$ Judges will recognize here what can be termed the "Galileo problem": someone has to be first, and new ideas must be accepted by the few before they can be accepted by the many.

Pseudoscience, by contrast, cannot be reformulated in terms that mainstream science can explore; the stated "principles" would have to be

15. Gardner, Science: Good, Bad and Bogus (cited in note 2).

16. Id at xiii.

17. Paul Thagard, Resemblance, Correlation and Pseudoscience, in Marsha P. Hanen, Margaret J. Osler \& Robert G. Weyant, eds, Science, Pseudoscience and Society 17 (Wilfred Laurier U Press, 1980).

18. Id at 20 .

19. Robert G. Weyant, Protoscience, Pseudoscience, Metaphors and Animal Magnetism, in Hanen, Osler \& Weyant, eds, Science, Pseudoscience and Society at 78 (cited in note 17) ("Animal Magnetism").

20. Id.

21. Fye y United States, 293 F 1013 (DC Cir 1923).

22. Weyant, Animal Magnetism at 79 (cited in note 19). 
reformulated so radically that the end result would not resemble the original system or would prove itself wrong when tested. ${ }^{23}$

What all critics of junk science share is the conviction that there is an ascertainable difference between scientific truth and falsehood. In its most extreme form this is nineteenth-century positivism, the view that scientific truth exists, can be discovered, and transcends time, place, and the individual scientist. ${ }^{24}$ Positivists, including Jordan and Jastrow, firmly believe in science as the source of objective and absolute truth, providing "simple mechanistic certainty." ${ }^{25}$ It has been suggested that positivism is refuted by such things as Heisenberg's uncertainty principle, but positivist views survive to this day, most robustly within the scientific community itself. Nobel Prize winner Sheldon Glashow, a physicist with more than a passing understanding of uncertainty, recently declared:

We [scientists] believe that the world is knowable, that there are simple rules
governing the behavior of matter and the evolution of the universe. We affirm that
there are eternal, objective, extrahistorical, socially neutral, external and universal
truths and that the assemblage of these truths is what we call physical science. Natural
laws can be discovered that are universal, invariable, inviolate, genderless and
verifiable. They may be found by men or women or by mixed collaborations of any
obscene proportions. Any intelligent alien anywhere would have come upon the same
logical system as we have to explain the structure of protons and the nature of
supernovae. ${ }^{26}$

Positivists thus deny any important interrelationship between the observer and the observed, at least at any scale above quantum effects. Culture and social context are not among the determinants of science.

At the other end of the spectrum, relativists believe that culture and context determine everything. Science is inextricably tied to its human, social, and historical surroundings. ${ }^{27}$ Relativists reject "the belief that there actually is out there somewhere a real, objective (non-ideological) body of truth called science" and uphold the view that "modern science itself was and remains the product of men in the activity of historically specific social relations." 28 Weyant, though he seems to lean toward the positivist camp, offers a milder statement of similar views, a statement that stands in sharp contrast to Glashow's:

23. Id at 80 (A pseudoscience, therefore, "is not only a non-science claiming to be a science, but it is judged either not to be amenable to reformulation or, if reformulated, not to be a potentially 'correct' science.").

24. For a fuller discussion of positivism and relativism, see Bert Black, A Unified Theory of Scientific Evidence, 56 Fordham L Rev 595, 615-21 (1988).

25. Id at 616 .

26. Sheldon Glashow, Positivism Lives: We Believe that the World is Knowable, NY Times E24 col 4 (Oct 22, 1989).

27. See Gerald Doppelt, Relativism and Recent Pragmatic Conceptions of Scientific Rationality, in Nicholas Rescher, ed, Scientific Explanation and Understanding 107 (U Press of America, 1983); Paul K. Feyerabend, Against Method: Outline of An Anarchistic Theory of Knowledge, in Michael Radner \& Stephen Winokur, eds, 4 Minnesota Studies in the Philosophy of Science-Analyses of Theories and Methods of Physics and Psychology 17 (U Minn Press, 1970).

28. Roger Cooter, Deploying "Pseudoscience": Then and Now, in Hanen, Osler \& Weyant, eds, Science, Pseudoscience, and Society at 40 (cited in note 17). 
No matter how much we like to believe that absolute demarcation criteria exist, the science/pseudoscience distinction is not a simple, straight-forward one, nor is it a wholly logical one, nor does it depend exclusively on empirical evidence. It is a judgment influenced by intellectual, social, political, economic, theological and scientific views of a particular time and place. So it is with all human judgments, science is no exception. ${ }^{29}$

Relativists go further, of course. They cheerfully contend that all judgment about science is subjective and relative, ${ }^{30}$ that if one looks at the history of science, the only rule is that "anything goes." 31 Drawing a line between science and pseudoscience, then, is itself a scientific judgment meaningful only in social context. ${ }^{32}$ There is thus no rational basis for distinguishing science from witchcraft.

One might think that lawyers, at least, would be able to avoid such debates, whether conducted in the quagmire of anecdote or on the alpine plateau of philosophy. Whatever others may think, the law can hardly doubt there is any such thing as truth, scientific or otherwise. "Truth," after all, is repeated like a mantra in the witness's oath. Surely the law does not require the expert witness to swear allegiance to something that judges and lawyers, as closet relativists, really do not believe exists. ${ }^{33}$

Yet oaths notwithstanding, the relativists have been doing notably well in legal circles of late. Whether or not Frye still lives-and its death has not been officially noted everywhere ${ }^{34}$-much of the conviction is gone. Many courts have been slouching toward the empty "relevancy" test for qualifying scientific evidence, ${ }^{35}$ toward what Judge Patrick Higginbotham of the Fifth Circuit has dubbed the let-it-all-in philosophy of evidence. ${ }^{36}$ As EPA General Counsel (formerly Yale Law Professor) E. Donald Elliott puts it, the law today "extends equal dignity to the opinions of charlatans and Nobel Prize winners, with only a lay jury to distinguish between the two." 37 "By early 1985," observes Edward J. Imwinkelried, author of a major treatise, Scientific Evidence, "the Frye test had been repudiated or seriously questioned in at least sixteen

29. Weyant, Animal Magnetism at 110 (cited in note 19).

30. For example, Paul K. Feyerabend, Problems of Empiricism, in Robert G. Colodny, ed, 2 Beyond the Edge of Certainty 145-46 (Prentice Hall, 1965).

31. Feyerabend, Against Method at 26 (cited in note 27).

32. See Black, 56 Fordham $\mathrm{L} \mathrm{Rev}$ at 621 (cited in note 24). See also Thomas S. Kuhn, The Structure of Scientific Revolutions 47 (U Chi Press, 2d ed 1970); Feyerabend, Problems of Empiricism at 14546 (cited in note 30 ).

33. For a compact, lucid discussion of positivism, relativism, and the history of science, see Black, 56 Fordham L Rev at 595 (cited in note 24).

34. Indeed, Frye remains theoretically on the books in a slight majority of jurisdictions. Edward J. Imwinkelried, The "Bases" of Expert Testimony: The Syllogisitic Structure of Scientific Testimony, 67 NC L Rev 1, 6 (1988).

35. Jack Weinstein, Improving Expert Testimony, 20 U Richmond L Rev 473, 477-78 (1986).

36. Eymard v Pan American Airways, 795 F2d 1230, 1234 (5th Cir 1986).

37. E. Donald Elliott, Science Panels in Toxic Torl Litigation: Why We Do not Use Them, in Symposium III, Immunotoxicology: From Lab to Law 115, 117 (Inst Comparative \& Envir Toxicology, 1987). 
states and four of the twelve federal circuits." 38 One court in every three thus opened the door wide "to testimony based on theories not generally accepted as factfinding tools within any scientific discipline."39

When all is said and done, the two main reasons for this trend seem to be Einstein and Galileo. Take Einstein first. Just because the scientist is a hermit does not necessarily mean he is wrong, even though he does march to his own, independent drummer, and even though he is shunned by his mainstream colleagues. Einstein's theories have been proven to be correct, after all. "General acceptance" by other scientists is meaningless, perhaps even an indication of orthodox error.

A more modest variation on this same argument invokes Galileo. Even if we grant that general acceptance is important in science, there is always the problem of timing. Maybe our maverick expert is not really a permanent hermit, he just appears that way for a time. His isolation is transienttemporal, not geographic. The rest will catch up soon enough. But meanwhile the legal proceedings must continue, as best they can, with whatever relevant evidence can be found.

In keeping with the medical experts it discusses, this is an unorthodox, hermetic, and idiosyncratic article. The first two sections are devoted to the law and science of two enduring controversies-traumatic cancer and cerebral palsy. The last section speaks to the Galileo fallacy directly.

I have resisted the urge to write a hortatory conclusion on revision of the rules of evidence, motions in limine, bifurcated trials, or court-appointed experts. The literature on these subjects is already large enough, and the tools for limiting junk science in court are already close at hand. What is most often missing is not the literature or the tools but the will to use them. In lieu of conclusion, Hering's gentle warning of 1924 will therefore serve as an excellent prologue:

It is hard to tell which exhibits the greatest departure from the normal: the eager chaser after the will-o'-the-wisp, who is so wholly possessed by his idea that it becomes an obsession ... or the admirers and victims themselves who, astute enough in general, are peculiarly susceptible to some particular form of deception[,] . . . even in some instances pleased at being humbugged. The scientific mind is necessarily an open mind, and the over-credulous imagine themselves especially scientific in their readiness to accept evidences of strange new truths. ${ }^{40}$

38. Edward J. Imwinkelried, Science Takes the Stand: The Growing Misuse of Expert Testimony, The Sciences 20, 22 (Nov/Dec 1986).

39. Id.

40. Hering, Foibles and Fallacies at 10 (cited in note 4). 


\section{Traumatic Cancer}

Anita Menarde's misfortune apparently began on the morning of May 16, 1949, when she was injured slightly while alighting from a Philadelphia streetcar. ${ }^{41}$ She sued of course. For breast cancer.

The facts did seem powerfully suggestive. Immediately after her fall, Menarde was treated at a local hospital for scrapes and bruises to her left ankle, right knee, and both hands. Dr. Koebert, her family doctor, saw her in the early evening. Upon disrobing later on that day she noticed a discoloration on her right side and breast. She called Dr. Koebert again the next day about the bruised breast; he examined it, found no lumps, and prescribed hot compresses. He examined her periodically for the next two months; the breast seemed perfectly normal. At the end of July, however, Anita detected a lump in her breast "at the exact spot" of the earlier bruise. Dr. Beck, a cancer specialist, diagnosed cancer; the breast was removed.

In the trial against the streetcar company, Dr. Koebert provided key support:

Q. Could there possibly have been something else which contributed to this cancer?

A. I do not think we are able to say.

Q. Can we say that this particular bruising or injury, to the exclusion of everything else, caused this cancer?

A. I believe other conditions which had happened, and according to the highlights of the case as I examined her originally, and in that it arose in that immediate area, I believe that this cancer was caused directly by the injury.

Q. Is it not possible that something else contributed to it?

A. Within the knowledge of man, I think not ....

Q. Would you say that it is impossible that there was any other thing that could have caused this cancer other than the blow?

A. In this case I would say not ....

Q. Doctor, is there even the slightest idea of speculation in your mind as to the judgment you have come to in concluding that this accident caused this cancer in this girl's body?

A. I believe that this accident was the direct cause of this woman's cancer.

Q. And is that judgment based on any speculation whatsoever in this case?

A. Not in this case, no. ${ }^{42}$

Dr. Beck acknowledged differences of opinion "among outstanding authorities" as to whether simple trauma could cause cancer. ${ }^{43}$ But in the end, he too agreed that in Menarde's case, at least, there was a connection. The jury awarded $\$ 50,000$, a considerable sum at the time, which the trial judge cut to $\$ 25,000$. A unanimous Pennsylvania Supreme Court affirmed. ${ }^{44}$

\section{A. Carcinogenic Money}

Junk science springs from many different impulses. Some proponents are just too eager to make profound new discoveries. Others embrace junk

41. Menarde v Philadelphia Transp. Co., 376 Pa 497, 103 A2d 681 (1954).

42. Id at 502, $103 \mathrm{~A} 2 \mathrm{~d}$ at 684

43. Id at 503, $103 \mathrm{~A} 2 \mathrm{~d}$ at 684

44. Id at $510,103 \mathrm{~A} 2 \mathrm{~d}$ at 688 . 
science for peace of mind because it seems to explain all sorts of otherwise terrifying mysteries. Without doubt, however, the greatest returns on junk science have always been paid in cash. We were once more candid about such things than we are today. A critic of quack medicine ads published in 1836 in James Gordon Bennett's New York Herald received the following straightforward reply from Bennett himself: "Send us more advertisements than Dr. Brandreth does-give us higher prices. We'll cut Dr. Brandreth dead .... Business is business-money is money. We permit no blockhead to interfere with our business."45

Money is money in the legal business too. Money is what brings claimants to court. Money pays their lawyers. Money attracts their expert witnesses. Money can, in fact, create experts where none existed before. It can fund chairs for the study of almost anything, real or imaginary.

By the time Anita Menarde arrived in court, her medical theory was almost three centuries old. In 1676, an eminent English surgeon, Richard Wiseman, had reported two interesting cases of cancer. ${ }^{46}$ Both patients, he observed, "thought [the cancer] came from an accidental bruise." 47 Wiseman agreed; he proceeded to identify bruises, "error in diet," and "ill handling" as among cancer's causes. ${ }^{48}$ In time, many doctors came to believe that simple trauma could trigger a malignant tumor.

By the mid-nineteenth century, however, the theory was in decline. Most physicians were beginning to understand that chronic irritation or abrasion, heat, and chemicals can cause cancer, but that simple trauma does not. In the normal course of things, the traumatic cancer theory would gradually have been relegated to the museum of scientific curiosities.

Then, quite abruptly, many doctors became believers once again. The rapid shift in medical attitudes began in Germany in 1884, and swept across the American continent in the first decades of this century. Individual doctors began to report frequently once again of trauma-cancer connections. ${ }^{49}$ Eager statisticians then set to work. Literature dating back to 1875 had suggested that one in eight tumors might be caused by previous trauma. ${ }^{50}$ By 1897 , another estimate blamed trauma for half of all bone cancers. ${ }^{51}$ As late as 1932, one researcher would attribute two out of five brain tumors to either physical trauma or purely psychological upset. ${ }^{52}$

45. As reported by Richard Harwood, Editorial, Washington Post 66 (Dec 10, 1989).

46. See Howard L. Stoll, Jr. \& John T. Crissey, Epithelioma from Single Trauma, NY State J Med 496 (Feb 15, 1962).

47. Quoted in Richard J. Behan, Relation of Trauma to New Growths: Medico-Legal Aspects 7 (Williams \& Wilkins, 1939).

48. This dietary error, for Wiseman, signified "a great acrimony in the meats and drinks with a fault in the first concoction, which not being afterwards corrected in the guts, suffered this acrimonious matter to ascend into the bloud - or if by any defect in those . . the humours divert to any peculiar part then the foundation of this disease is laid, whether in the breast." Quoted in id.

49. For example, Jonathan M. Wainwright, Single Trauma, Carcinoma and Workman's Compensation,

5 Am J Surg 433 (1928).

50. Everett L. Bishop, Cancer, Trauma, and Compensation, $32 \mathrm{~S}$ Med J 302, 305 (March 1939).

51. Id.

52. See Leila C. Knox, Trauma and Malignant Tumors, 26 Am J Surg 66, 69-70 (Oct 1934). 
Had there been a breakthrough in laboratory work, or an eye-opening epidemiological study? No. What had changed was the law. Germany had introduced the world's first worker's compensation program in 1884 . Between 1884 and 1897, 2,000 new books and papers on traumatic cancer were published in Germany alone. ${ }^{53}$ By the early 1920s, all but eight American states had enacted worker's compensation laws, too, and the traumatic cancer epidemic had reached American shores. The one new fact on the medical scene was that attributing cancer to trauma helped pay bills all around. As one exasperated observer would note in 1959, the carcinogenic properties of trauma "increase in potency each year and in direct proportion to the broadening of insurance coverage." 54

\section{B. Metastasis in Court}

At first the prospects in court for traumatic cancer claims did not look promising. One early traumatic cancer case, for example, was filed by Levy D. Jewell, who had been hit on the arm while loading freight onto a train..$^{55}$ A jury awarded him $\$ 960$ for his subsequent cancer. The New Hampshire Supreme Court, however, was deeply skeptical when the case reached it in 1874: " $[1] \mathrm{t}$ would be a reproach upon the administration of the law if such mere speculative possibilities, unsustained by proof, were permitted to become the basis of awarding heavy damages of this sort," 56 wrote Justice Isaac W. Smith. "Few things are more difficult, and require more close observation, than the just determination of the causes of disease, or the effects of injuries to the person," 57 agreed Chief Justice Edmund L. Cushing. The award was overturned, though ultimately on other grounds. Other courts of that era were equally firm in rejecting such claims. As late as 1921, for example, the Iowa Supreme Court overturned an award for stomach cancer allegedly caused by breaking a leg in a fall into an elevator pit. ${ }^{58}$ The expert testimony, the court declared, was "wholly in the realm of conjecture, speculation, and surmise."59

As worker's compensation laws proliferated, however, many judges joined the ranks of the conjecturists and speculators. When Candelario Villa injured his left clavicle in a work-related accident, he, his wife, and a friend all testified that they immediately saw the bump that eventually was diagnosed as cancerous. ${ }^{60}$ Villa's doctor noticed it a few days later. All the doctors who

53. See Stoll \& Crissey, NY State J Med at 496 (cited in note 46).

54. Comment, Sufficiency of Proof in Traumatic Cancer: A Medico-Legal Quandary, 16 Ark L Rev 243, 267 (1962) (authored by Darrell W. Johnson), quoting Reynolds Crane, The Relationship of a Single Act of Trauma to Subsequent Malignancy, reprinted in Alan R. Moritz \& David S. Helberg, Trauma and Disease Selections from the Recent Literature 147 (Central Book, 1959).

55. Jewell v Grand Trunk Railroad, 55 NH 84 (1874).

56. Id at 96 .

57. Id at 95.

58. Slack v C.L. Percival Co., 198 Iowa 54, 56, 199 NW 323, 327 (1924).

59. Id at 56, $199 \mathrm{NW}$ at 326 .

60. Santa Ana Sugar Co. v Industrial Accident Commission, 35 Cal App 652, 170 P 630 (1917). 
testified agreed that cancer would take at least a few days to develop after a blow. A worker's compensation award was upheld anyway. ${ }^{61}$

Proof of similar character would suffice for most U.S. courts for the next half century. A blow to the face with a piece of coal caused cancer at the spot some weeks later, agreed the Colorado Supreme Court in 1922.62 A violent assault on a policeman during an arrest caused abdominal cancer six weeks later, the Minnesota Supreme Court was persuaded in 1923.63 A five-foot fall from an elevator caused cancer of the rib, concluded the Virginia Supreme Court in 1927.64 Two severe blows to the testicles caused malignant cancer seven days later, a Texas appellate court found in 1941.65 A blow from a large can of orange juice caused breast cancer, the Rhode Island Supreme Court allowed in $1949 .{ }^{66}$ Bone cancer developed from a twist to the leg caused by heavy lifting, the New Mexico Supreme Court found in 1958.67

In time, traumatic cancer claims spilled over to ordinary tort cases, wholly outside the realm of worker's compensation laws. This is how Anita Menarde came to collect for breast cancer caused by her accident while riding a Philadelphia streetcar. Others won similar claims. In 1963, Jack Murdock was thrown violently against his fastened seat belt when his car was hit from behind. 68 "[A] possibility exists," a doctor later testified, that "trauma induced by pressure from a seat belt might have led to an inflammatory condition in the testicles," which might "conceivably" have triggered cancer in Murdock's left testicle. ${ }^{69}$ A Georgia court of appeals agreed. A year later the cancer victim was Marie P. Daly, who bruised her breast and broke her leg in a fall at the Duffy Brother store in Rosemount, Minnesota. ${ }^{70}$ When she developed breast cancer fourteen months later, one physician discerned a connection, six did not, and the jury awarded $\$ 40,000.71$ Another 1964 case involved a rear-end collision that threw Jerome Baker against the steering wheel of his car. ${ }^{72}$ His chest was bruised; two months later he died of lung cancer. A jury verdict for the plaintiff was upheld by the Pennsylvania Supreme Court. ${ }^{73}$

What is most remarkable in the hey day of such lawsuits is just how many different kinds of things could be bumped, banged, or collided with to cause cancer. Streetcars, metal bobbins, ${ }^{74}$ slippery floors in grocery stores, hot

61. Id at 653-54, 170 P at 631.

62. Canon Reliance Coal Co. v Industrial Commission, 72 Colo 477, 211 P 868 (1922).

63. Gaetz v City of Melrose, 155 Minn 330, 193 NW 691 (1923).

64. Winchester Milling Corp. v Sencindiver, 148 Va 388, 138 SE 479 (1927).

65. Traders and General Insurance Co. v Tumer, 149 SW2d 593 (Tex Civ App 1941).

66. Emma v A.D. Julliard ثं Co., 75 RI 94, 63 A2d 786 (1949).

67. White v Valley Land Co., 64 NM 9, 322 P2d 707 (1958).

68. National Dairy Products Corp. "Durham, 115 Ga App 420, 154 SE2d 752 (1967)

69. Id at 422,154 SE2d at 754 .

70. Daly $v$ Bergstedt, 267 Minn 244, 126 NW2d 242 (1964).

71. Id at 248-49,126 NW2d at 245-46.

72. Baker v DeRosa, 413 Pa 164, 196 A2d 387 (1964).

73. Id at 172-73, 196 A2d at 391-92.

74. Valente U Bourne Mills, 77 RI 274, 278-79, 75 A2d 191, 194 (1950). 
water heaters, ${ }^{75}$ umbrella handles, ${ }^{76}$ car dashboards, ${ }^{77}$ a can of orange juice, and a forty-pound box of cheese, to name just a few. Since the thigh bone connects to the hip bone and all that, blows are sometimes nearer, sometimes farther from the site where cancer eventually develops. Lifting heavy cheese in one case put "such a strain upon the muscles which were connected, or nearly so, with the diseased tissues, that is, the cancer," 78 that the lifting undoubtedly hastened the cancer's progression. Abdominal pressure from a seatbelt might have inflamed the testicles, which "might conceivably squeeze the tumor cells into circulation and into adjacent areas."79 In a 1954 ruling, the Ohio Supreme Court approved compensation to a worker who claimed to have been struck on the left side of his chest by a heavy piece of equipment on the last day of his employment. ${ }^{80}$ Cancer was later found in his right lung. The worker's widow, however, located an expert who believed in the "contracoup" theory, whereby the cancerous effects of chest trauma cross the body in just this way. ${ }^{81}$

Here and there some judges did demur. Four dissenting Georgia judges, for example, consign the evidence on testicular-cancer-by-seatbelt to "the scrap heap of conjecture," and point out that so far as trauma and cancer are concerned, the same plaintiff had been involved in three other car accidents, and had even shot himself in the leg with a .22 caliber pistol. ${ }^{82}$ Two dissenting Pennsylvania justices are equally skeptical of the "farfetched contradictions" and "conjectures" in the lung-cancer-by-car-accident case. ${ }^{83}$ So are two dissenting New Mexico justices in a bone-cancer-by-heavy-lifting ruling who refuse to accept such testimony: "If the judgment in this case can be upheld, ... there is not an ailment in the whole category of disease known to the medical profession that may not become the basis of a workmen's compensation award." 84 Occasionally such views even coalesce in the majority. In 1948, the Washington Supreme Court rejects a jury finding that fractured bones in a foot worsened into arthritis of the spine, eventually causing cancer of the intestine ten years later, ${ }^{85}$ even though one doctor did testify that there "probably could" be a connection. But until well into the 1960 s, such opinions remain the exception. Most appellate decisions up to that time side with claimants.

75. Vilale v Duerbeck, 338 Mo 556, 92 SW2d 691 (1936).

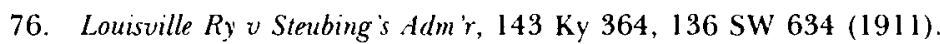

77. Hanna v Aetna Insurance, 24 Ohio Misc 27, 259 NE2d 177 (1970).

78. Boyd et al y Young, 193 Tenn 272, 246 SW2d 10, 12 (1951).

79. National Dairy Products ข Durham, 115 Ga App 420, 154 SE2d 752 (1967).

80. Glenn v National Supply, 101 Ohio App 6, 129 NE2d 189 (1954).

81. Id at 10,129 NE2d at 192 .

82. National Dairy, 115 Ga App at 425-26, 154 SE2d at 755-56 (Bell, Frankum, Jordan, and Eberhardt dissenting).

83. Baker 'DeRosa, 413 Pa 164, 173, 196 A2d 387, 392 (1964) (Bell and Jones dissenting).

84. White v Valley Land Co., 64 NM 9, 17, 322 P2d 707, 712 (1958) (Sadler and McGhee dissenting).

85. Tonkovich v Dep't of Labor Ë Indus., 31 Wash 2d 220, 226-27, 195 P2d 638, $641-42$ (1948). 


\section{Rationalizations}

How could so many judges get the science so wrong, in so many different cases, spanning so many years? Some, no doubt, really did believe in traumatic causes. Many more saw only a 1930 's worker or widow who really could use the money. In dubio pro laeso-when in doubt, favor the injured.

Still, someone must supply at least a shadow of a dubio, and this is where the junk science in court really flowered. The traumatic cancer cases present a catalog of bad observation, worse logic, wishful thinking, and epidemic judicial credulity.

The credulity was the easy part. Often, judges were able to blame others for the science, and many gratefully did. By state law, worker's compensation boards usually made the initial call on the validity of the claim. Sympathetic judges could then simply suspend disbelief and humbly defer to the expertise, such as it was, of the compensation board. The board, of course, could do the same thing, by humbly deferring to the family doctor. And the family doctor surely understood that the one bit of good he could do for his unfortunate patient was to testify with an unusually open mind, even if the testimony had to be cocooned in "mights," "maybes," and "possibles." And so, everyone deferred to everyone else, except the first general practitioner, who deferred to no one. When the deferential bowing and scraping was over, the insurer paid.

The less courts required of medical witnesses, the less witnesses supplied. In one case, a first doctor allowed that the blow "might" have caused the cancer, although probably not; a second that cancer "may result from a blow," the inference being "possible, but not reasonably probable"; a third that the blow "might be a contributing cause," though not to "a reasonable probability." 86 For the Minnesota Supreme Court, these views were enough to support an award. Over time, expert witnesses came to recognize how very little was required and grew all the more willing to testify. Even a great scientist can concede that fairies might possibly once have appeared in England, and may perhaps have been photographed by some young friends of Sherlock Holmes's biographer, Sir Arthur Conan Doyle, though of course it's not very probable.

Appellate courts grew increasingly adept at accommodating this sort of thing; the key was always to locate an accommodating expert somewhere in the trial record and give credit accordingly. In late 1941, for example, nineteen-year-old Charles Ellis was working for the Virginia State Highway Commission. He did not report the incident at the time, but as he later remembered it, a falling rock dislodged by rain struck him one day on the leg. ${ }^{87}$ Soon after, doctors discovered bone cancer. "[I]t is a well established and recognized fact in the medical profession," one doctor would testify, "that trauma, especially occurring to young people, is the sole cause of many

86. Gaetz v City of Melrose, 155 Minn 330, 193 NW 691 (1923).

87. Ellis v Commonwealth, 182 Va 293, 28 SE2d 730 (1944). 
malignancies developing shortly thereafter and that the result which followed in the instant case is a common one." 88 But a pathologist was quite certain that bone cancers of this type are not caused by rocks, and he persuaded the compensation board to deny damages. The Virginia Supreme Court overturned the board's ruling and ordered payment. The young worker, the Court emphasized, had been "attended by two experienced and competent physicians" who were "thoroughly familiar with all of the conditions" of both the trauma and the cancer. The defense's experts had given only a "theoretical opinion." "The positive opinions of the two attending physicians" must outweigh "the general view of the medical authorities," the court declared. 89

Playing the experts off against each other in this way was straightforward. The judge would routinely lament "the usual conflict of medical opinion,"'90 then endorse the check. In 1958, for example, James Bentley recovered for cancer of the jaw because (by his own unverified account) he had earlier cut his lip on a cardboard carton. ${ }^{91}$ One testifying doctor was sure the cut had caused cancer on the lip that spread to the jaw. A pathologist was quite certain that cuts do not cause cancer. A third doctor, who had actually treated Bentley, testified only that the cancer had originated on the lip. " $[\mathrm{I}] \mathrm{t}$ is possible that the trauma might play a part or be a factor. I am not saying it produced it. I am saying that it may be a factor in the production of this lesion." 92 This span of opinions was quite enough for the Michigan Supreme Court.

The record is replete with medical assertions of lack of positive knowledge about the cause of cancer. And yet, with all this uncertainty, the patient was diagnosed and treated. The appeal board had the task assigned by statute to make [a] finding of fact .... We cannot say that its decision is unsupported by competent evidence. ${ }^{93}$

Under a "not unsupported" standard, of course, traumatic cancer was going to endure forever. Sympathetic family doctors or imaginative medical mavericks were always going to be located, somewhere or other, to "not unsupport" traumatic cancer claims. ${ }^{94}$

Picking and choosing among witnesses and compensation boards was easy. Most appellate courts, however, recognized their obligation to do somewhat more. Accordingly, they marched through a textbook demonstration of junk science observation and reasoning in action.

Trauma can have caused cancer only if there was no cancer beforehand, so the court had to establish that first. That was easy enough: friends, family, or even lawyers could testify to a plaintiff's pre-trauma health by simply stating that, prior to the accident, the claimant was "a perfectly healthy, strong man

88. Id at $295,28 \mathrm{SE} 2 \mathrm{~d}$ at 732 .

89. Id at 305,28 SE2d at 735 .

90. Mallfield v Ward Baking Co., 14 AD2d 942, 221 NYS2d 224 (1961).

91. Wilson y Dophler-Jarvis Division of National Lead Co., 353 Mich 363, 91 NW2d 538 (1958).

92. Id at $372,91 \mathrm{NW} 2 \mathrm{~d}$ at 542.

93. Id, $91 \mathrm{NW} 2 \mathrm{~d}$ at $542-43$.

94. George R. Monkman. Gregg Orwoll \& John C. Ivins, Trauma and Oncogenesis, 49 Mayo Clinic Proceedings 157, 162 (1974). 
who has never lost any time from work or complained of any illness." 95 In one early case, an autopsy showed that the victim was suffering from tuberculosis, Bright's disease, acute and chronic cystitis, acute and chronic prostatitis with abscess formation, and chronic selenitis. ${ }^{96} \mathrm{~A}$ court nevertheless agreed with a jury's finding that death was from cancer caused by a fall from a streetcar twenty months earlier. ${ }^{97}$

Some courts were equally nonchalant about the trauma itself. No matter that the employee failed to report the blow until after the cancer was diagnosed. No matter that the whiplash, or the impact against the steering wheel, seemed inconsequential at the time. Trauma and cancer are connected, the Virginia Supreme Court reasoned in 1927, but "the degree of injury plays no important part." 98 " "[T]he connection between trauma and the subsequent development of sarcoma," the Minnesota Supreme Court observed in 1931, " "may be many times overlooked due to the triviality of the injury. Just a mere bump the patient does not remember." "99

With the health-trauma-cancer sequence established to the court's satisfaction, the rest was easy. There was no rest: the sequence was everything. " $[I] \mathrm{t}$ should be recognized that inferences, if rational and natural, which follow from a sequence of proved events, may be sufficient to establish causal connection without any supporting medical testimony." 100 This quote comes from the Minnesota Supreme Court in 1964, but virtually identical language appears in dozens of other rulings of that era. The Rhode Island Supreme Court overturned a lower court ruling and determined that a light, glancing blow to the nipple caused the breast cancer discovered some weeks later. ${ }^{101}$ Where "injury appears in a bodily member reasonably soon after an accident, at the very place where the force was applied," the court reasoned, there arises "a natural inference that the injury, whatever may be the medical name . . . was the result of the employment."102 And what of statistical evidence establishing that such sequences are just meaningless coincidence? "Facts prevail over possibilities or probabilities," wrote one court dismissively. ${ }^{103}$

Some courts thus defer to bad science; other courts endorse the bad data and spurious inferences themselves. Still others find ways to explain why science should not really be dispositive at all. Some reason that "cause" does not mean quite the same thing in law as in science. ${ }^{104}$ "Causation is not

95. Ellis $v$ Commonwealth, 182 Va 293, 28 SE2d 730 (1941).

96. Ben F. Small, Gaffing at a Thing Called Cause: Medico-Legal Conglicts in the Concept of Causation, 31 Tex L Rev 630, 640 (June 1953), citing Thompson v New Orleans Ry E Light Co., 145 La 805, 83 S 19 (1919).

97. Id.

98. Winchester Milling Corp. v Sencindiver, 148 Va 388, 395, 138 SE 479, 481 (1927).

99. Hertz y Watab Paper Co, 184 Minn 1, 3, 237 NW 610, 611 (1931) (quoting testimony).

100. Daly y Bergstedt, 267 Minn 244, 247, 126 NW2d 242, 247 (1964).

101. Valente v Bourne Mills, 77 RI 274, 278-79, 75 A2d 191, 194 (1950).

102. Id at $279,75 \mathrm{~A} 2 \mathrm{~d}$ at 194.

103. Ellis v Commonweallh, 182 Va 293, 306, 28 SE2d 730, 735 (1941).

104. Small, 31 Tex L Rev at 657-58 (cited in note 96). 
nécessarily and exclusively a medical conclusion,"105 one court explained. "[T]he doctor is thinking in terms of a single, precise cause for a particular condition," noted another court, but the law "recognizes more than one cause for a particular injurious result."'106

This sort of thing could always be reinforced by an appeal to common sense and the intuition of the layman. "When there is such a divergence of competent medical opinion, we, as laymen, must necessarily look to the facts for a way out of a seeming dilemma," reasoned the Michigan Supreme Court in 1947.107 "The lay mind, under such circumstances, can reach no other conclusion than that . . . the sarcoma was either caused by the injury or was aggravated by it," noted another court. ${ }^{108}$ The evidence "would be quite convincing to the mind of the layman," noted yet another, and that was enough. ${ }^{109}$

A few courts just rejected science altogether. The trauma-cancer link should not be determined "by nice philosophical reasoning, nor by the reluctance and hesitancy of the scientist to accept as satisfactory a conclusion not demonstrated to be necessarily a fact to a scientific certainty," declared the Rhode Island Supreme Court in 1949.110 "An inference, if rational and natural, based on proven facts, will stand even though not supported by expert medical opinion," the same court announced in another case the following year.111 Of course we cannot wait for "medical evidence establishing indisputable causal connection," reasoned the New Mexico Supreme Court in 1958.112 "Medical men are justifiably reluctant to make a definite statement" because "they have no actual knowledge at the present time on which such a statement could in all good conscience be made." 13 In court, however, the cancer connection remained "inferable despite the lack of medical evidence." 114

Now that you mention it, science really is remarkably ignorant about cancer, and that in itself may be reason enough to uphold the award. "The whole subject is shrouded in . . . mystery," observed the Supreme Court of Colorado in 1922.115 Either trauma causes cancer or cancer remains "a medical mystery," allowed the Supreme Court of Minnesota in 1925, ${ }^{16}$ and if

105. Hammond v Fidelity and Casualty of $N Y, 419$ S2d 829 (1981), quoting Haughton v Fireman's Fund American Insurance Co, 355 S2d 927, 928 (La 1978).

106. Daly v Bergstedt, 267 Minn 244, 249, 126 NW2d 242, 246 (1964), quoting Murray v Industrial Comm., 87 Áriz 190, 199, 349 P2d 627,633 (1960).

107. Mooney y Copper Range R. Co., 318 Mich 120, 127, 27 NW2d 603, 606 (1947).

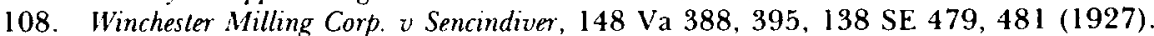

109. Austin v Red Wing Sewer Pipe Co., 163 Minn 397, 398, 204 NW 323, 323-24 (1925).

110. Emma v A.D. Julliard $\Theta$ Co., 75 RI 94, 96-97, 63 A2d 786, 788 (1949), citing the trial court

111. Valente v Bourne Mills, 77 RI 274, 278-79, 75 A2d 191, 194 (1950).

112. Comment, Sufficiency of Proof in Traumatic Cancer Cases, 46 Cornell L Q 581, 582 (1961) (authored by George R. Parsons, Jr.), citing White v Valley Land Co., 64 NM 9, 15, 322 P2d 707, 711 (1958).

113. Valley Land Co., $64 \mathrm{NM}$ at 15,322 P2d at 711 .

114. Id.

115. Canon Reliance "Industral Commission, 72 Colo 477, 480. 2 11 P 868, 869 (1922).

116. Austin " Red Wing Seuser Pipe Co., 163 Minn at 398, $204 \mathrm{NW}$ at 324. 
it's all a mystery, who's to say that the claimant should not be paid? "This record is replete with medical assertions of lack of positive knowledge about the cause of cancer," declared the Michigan Supreme Court in 1958, ${ }^{117}$ citing a law review article as its medical authority. "It appears that none of [the six doctors who testified] knows the cause of the petitioner's cancer," explained the Tennessee Supreme Court in 1970 , so the award was naturally upheld. ${ }^{118}$ Thus, judges invoked ignorance of the facts as their main excuse.

\section{Hammering the Rooster}

While family practitioners speculated, compensation boards deferred, judges rationalized, and juries voted, the mainstream scientific community was off working out the facts. In the United States, the work was led by an American pathologist, James Ewing. Drawing on his own work and analyzing other reports and studies, Ewing began publishing authoritative papers on traumatic cancer in the mid-1920s. $119 \mathrm{He}$ accepted the possibility that trauma might, in some very rare instances, cause cancer. He recognized, however, that even if such things ever occurred, trauma was being blamed far too often.

By 1935, Ewing had assembled in a major treatise both his own work and the consensus views of medical scientists. ${ }^{120}$ He presented five postulates that must be met before trauma-induced cancer could be considered plausible. ${ }^{121}$ First, you have to be quite sure there really was a trauma; vague patient recollections cannot suffice. It requires "time, patience, and ingenuity to establish the facts"; unless this inquiry is "competently made, the report of the case [is], for scientific purposes, worthless."122 Second, you must establish convincingly that the cancer did not come first. ${ }^{123}$ Since most people are not medically examined shortly before a traumatic car accident or on-the-job injury, and since early-stage cancer is difficult to detect in any event, most reports of cancer discovered sometime after trauma are meaningless. Third, the tumor must originate at the exact point of the earlier trauma; general vicinity is not enough. Fourth, the time interval between the trauma and the appearance of the cancer must be biologically reasonable; cancers from chronic irritation never develop in less than five years, and incubation periods of ten to twenty years are more typical. Fifth, the cancer must be diagnosed positively; a biopsy must be performed.

117. Wilson v Doehler-Jarvis Division of National Lead Co., 353 Mich 363, 372, 91 NW2d 538,542 (1958).

118. Koehring-Southern v Burnette, 225 Tenn 147, 152, 464 SW2d 820, 822 (1970)

119. See, for example, James Ewing, The Relation of Trauma to Malignant Tumors, Am J Surgery 30 , 31-34 (1926); see generally Monkman, Orwoll \& Ivins, 49 Mayo Clinic Proceedings 157 (cited in note 94).

120. James Ewing, Modern Attitudes 7oward Traumatic Cancer, 19 Archives of Pathology 690 (1935).

121. Id at 694-99.

122. Id at 692 .

123. Few traumatic cancer claimants of the day had had even a cursory examination for signs of cancer before the trauma, let alone the microscopic examination necessary to prove definitely that cancer did not exist beforehand. Ewing pointed out that strict adherence to this postulate would climinate many claims. Id at 695 . 
These postulates were already familiar to doctors in the field when Ewing published them in 1935. Of course you cannot find cause and effect unless you are careful about recording cause (postulate 1) and effect (postulate 5). Of course you have to check that the effects were not there before the cause (postulate 2). And of course the links must make some kind of biological and physical sense (postulates 3 and 4). Ewing's purpose was horticultural-to weed out junk cases that were stifling scientifically useful data. ${ }^{124}$

As the grubbing and uprooting proceeded, the flowers of serious science soon bloomed once again. Football players do not have higher rates of cancer than the crowds in the stands. Systematic studies of World War I veterans found no cancer correlation with wartime injury. Broken bones are extremely common, but bone cancer is rare and statistically unrelated to prior fracture. Patients who undergo surgery do not develop skin or tissue cancer near the incision more often than elsewhere or more often than anyone else. Controlled studies show no positive correlation between head trauma and brain tumors; to the contrary, some correlations seem to run the other way, though researchers prudently refrain from announcing that head trauma cures brain cancer. Laboratory crushings, hammerings, and smashings of various parts of laboratory animals, from rooster testicles on out, produce nothing but the expected mutilation. As a 1974 literature review in the Mayo Clinic Proceedings firmly concludes: " $[\mathrm{N}] \mathrm{o}$ experimental evidence ever has shown that trauma-single, uncomplicated trauma-produces cancer." 125

\section{E. Remission}

For much of the twentieth century, single, uncomplicated trauma produced pro-plaintiff cancer verdicts in steady numbers. Appellate decisions upholding traumatic cancer awards rose steadily from the 1920s through the 1950s. About three in four jury verdicts awarded plaintiffs some compensation. Only in the 1960s did Ewing's postulates at last begin to register in legal circles; however, traumatic cancer litigation did not finally drop off the charts until the 1970s, more than thirty years after Ewing's seminal work. ${ }^{126}$

Traumatic cancer litigation did finally abate in the end. The once sacrosanct expertise of the compensation tribunal began to be desecrated

124. His postulates were "not, as some lawyers have stated, a confession by the medical and scientific professions that some cancers are caused by single uncomplicated trauma." Monkman, Orwoll \& Ivins, 49 Mayo Clinic Proceedings at 159 (cited in note 94).

125. Id at 162. Another researcher wrote in 1955: "A critical analysis of the factual background of the concept [that trauma causes cancer] readily shows that there is not only a complete lack of supporting experimental evidence but also a remarkable deficiency of convincing human experience." W.C. Hueper, Medicolegal Aspects of Cancer, 25 Am J Clinical Pathology 116 (1955).

126. I base these statements on an informal survey of LEXIS case reports from four statesMinnesota, Texas, New Jersey, and New York in the periods mentioned. Cases were pulled from LEXIS using a broad search for trauma and cancer. Retrieved cases that obviously did not involve traumatic cancer were then discarded. Leslie Kyman, at that time my paralegal assistant (now a lawyer in her own right), did the counting. 
with some regularity. ${ }^{127}$ Judges also grew increasingly willing to set aside the testimony of maverick witnesses and reject post-hoc reasoning.

The New York Court of Appeals overturned a $\$ 45,000$ jury award in 1952 , in yet another case claiming breast cancer by car accident. ${ }^{128}$ The Ohio Supreme Court rejected another car-accident cancer claim in $1954 .{ }^{129} \mathrm{New}$ York courts solidified their support of Ewing three years later, in a claim of cancer caused by the metal flap of a paper towel holder striking the bridge of the plaintiffs nose. ${ }^{130}$ Other courts gradually followed. Traumatic cancer, the Texas Supreme Court announced in 1966, is "a question of science determinable only from the testimony of expert medical professionals," and is not to be inferred simply from a sequence of events. ${ }^{131}$ The Montana Supreme Court issued a similar opinion the same year, in a case involving cancer of the vertebrae attributed to a blow from farming machinery. ${ }^{132}$ In 1967, a New York appellate court rejected a jury's finding that a soda machine operator developed cancer via a slip and fall on the sticky floor of the Fourteenth Street subway station in New York City. ${ }^{133}$ And in 1969, after a jury had been persuaded that whiplash from a rearend collision caused metastasis of a throat cancer, the South Carolina Supreme Court declared that "[t]he narration of the sequence of events" could simply not suffice to prove that the condition developed in a manner other than it was naturally expected to develop. ${ }^{134}$

As courts began to question these jury awards, well-advised litigants kept their claims alive by altering them ever so slightly. Trauma did not "cause" cancer after all, these revised arguments stated, but it did aggravate or accelerate the cancer. ${ }^{135}$ The Minnesota Supreme Court approved a worker's compensation award that linked the progress of a malignant breast tumor to a blow from a drill on the nipple of a man's right breast. ${ }^{136}$ The Supreme Court of Tennessee agreed that injury to the back and left foot accelerated metastasis of some other cancer of uncertain origin. ${ }^{137}$ A Louisiana appellate court accepted cancer acceleration from a bruise to the leg, ${ }^{138}$ ignoring the

127. See, for example, Insurance Co. of North America v Myers, 411 SW2d 710 , rev'd, 399 SW2d 932 (Tex Civ App 1966).

128. Dennison v Wing, 279 AD 494, 496-97, 110 NYS2d 811,813.14 (1st Dept, 1952).

129. Lopresti $v$ Community Traction, 160 Ohio 480, 117 NE2d 2 (1954).

130. Frankenheim v B. Altman E Co., 13 Misc 2d 1079, 177 NYS 2d 302 (1958).

131. Insurance Co. of North America v Myers, 411 SW2d 710,713 (1966).

132. Stordahl v Rush Implement Company, 148 Mont 13, 19-20, 417 P2d 95, 99 (1966) ("Not every supposition or theory of a witness concerning what might be has the force of evidence, even though he be licensed to practice medicine. . . Everything in this troubled world is 'possible' and this is particularly true in the scientific world.").

133. Sikora v Apex Beverage Corp., 282 AD 193, 196, 122 NYS2d 64, 66 (1953), aff'd, 306 NY 912 , 119 NE2d 601 (1954).

134. Gambrell v Burleson, 252 SC. 98, 107-08, 165 SE2d 622, 626 (1969)

135. The "aggravation" theory had been around for much longer, of course, and appears frequently enough in the earlier decisions, too. Traders E General Insurance Co. v Tumer, 149 SW2d 593 (Tex Civ App 1941). In the later years, however, it displaces all others.

136. Pittman v Pillsbury Flour Mills, Inc., 234 Minn 517, 48 NW2d 735 (1951).

137. Koehring-Southern v Bumette, 225 Tenn 147, 464 SW2d 820 (1970).

138. Reed i Mullin I'ood Co., 274 S2d 845 (La App 1972), cert denied, 275 S2d 792 (La 1973 ). 
views of the one cancer specialist in the case, who concluded that the trauma had probably helped save the victim's life by bringing attention to disease already developing.

When even "aggravation" wore thin, some courts took final refuge in a vocabulary so empty that it no longer admitted to scientific contradiction. Johnny Hammond became one beneficiary of this kind of lego-babble after his cancerous arm was bruised by the steering wheel when his truck struck a pothole. All medical witnesses agreed that trucks striking potholes do not cause bone cancer. The trial court agreed as well, as did a court of appeals. In 1979, however, four of seven justices on the Louisiana Supreme Court ruled otherwise. ${ }^{139}$ "[M] $[\mathrm{M}$ edical testimony 'must be weighed in the light of other credible evidence of a nonmedical character, such as a sequence of symptoms or events," " the court declared. ${ }^{140}$ "'The employee's disability is compensable if a preexisting disease or condition is activated or precipitated into disabling manifestations as a result of a work accident." 141 Another cancer-by-pothole award went to a New York bus driver in 1985. ${ }^{142}$ An X-ray revealed that the wrist broken in the accident had been weakened by cancer; fortunately, the cancer, once revealed, could be promptly treated. At whose expense? The employer's, of course. "[I]t is sufficient," the New York Court of Appeals declared, "if the employment acts upon that disease or condition in such a manner as to cause a disability which did not previously exist." 143 "The growth in claimant's wrist was asymptomatic and not disabling prior to the accident. Indeed, plaintiff did not know that it existed." 144

Thus the word "cause" quietly slinks out of the legal vocabulary, to be replaced with "activated," "precipitated into disabling manifestation," "aroused into disabling reality," and other lawyerly evasions. Or else "cause" finds itself paired with legal vacuities (like "disability") rather than medically meaningful terms (like "cancer"). The claims once serious are now trivial, once specific are now surpassingly vague, once factual (though baseless) are now so a-factual that they are entirely beyond scientific refutation. Cause and effect are gently verbalized out of existence, though money continues to change hands. As the physicist Wolfgang Pauli once remarked about an article he was supposed to referee, "That paper is not even good enough to be wrong!"

\section{F. Traumatic Determinism}

No one could have been less surprised by this last chapter of the traumacancer chronicles than Ewing himself. Simple trauma does not in fact cause

139. Hammond "Fidelity and Casualty of New York, 407 S2d 13 (La App 1981), rev'd, 419 S2d 829 (La 1982).

140. 419 S2d at 831, quoting Schouest v J. Ray McDermoll E Co., 411 S2d 1042, 1044-45 (La 1982).

141. Id at 832 .

142. Pezzolanti " Green Bus Lines. 114 AD2d 553, 494 NYS2d 168 (3d Dept, 1985).

143. Id at 554, 494 NYS2d at 169, quoting Perez v Pearl-Wick Corp., 56 AD2d 239, 241, 392 NYS2d 496, 498 (3d Depı, 1979).

144. Pezzolanti, 114 AD2d at 553, 494 NYS2d at 169. 
cancer. Cancer does sometimes cause trauma. No, cancer does not cause a bus to hit a pothole. But cancer can make bones, breasts, and other body parts unusually susceptible to accident. "The presence of an unsuspected tumor tends to bring about the occurrence of injuries at the tumor bearing area and to intensify the subjective symptoms and local effects of the injuries," Ewing observed. ${ }^{145}$ The bulk of a tumor might make a blow more painful. The bone cancer might make a leg more susceptible to breaking. And yes, the cancer occasionally will directly cause the trauma. A man is found unconscious at the bottom of the stairs. He later suffers recurrent headaches and vertigo. When the brain tumor is finally discovered, it is all too easy to say it was caused by the fall. But, in fact, it was the tumor that caused the first dizzy spell that caused the fall.

Ewing called this kind of event "traumatic determinism." The suggestive sequence of events in fact implies just the opposite of what the layman commonly infers. As the South Carolina Supreme Court recognized in a 1980 case involving cancer and a door hinge striking the plaintiff's arm, "[y]ou really do not know how many times a day you hit your thumb until you have a sore thumb, and then it seems like you are hitting it every five minutes. . . [Y]ou are not aware of it until you have something that calls your attention to it."'146

For just this reason, trauma is often the best possible accident that could befall the cancer victim. The one thing that a broken bone, sprained back, or bruised chest undoubtedly does cause with some frequency is a visit to the doctor. "[T]raumas reveal more malignant tumors than they cause," Ewing noted in 1935.147

What does serious science have to say about the "aggravation" theory? To this day, one school of thought maintains, as did Ewing, that in certain rare instances, trauma may aid the spread or accelerate the development of an already existing cancerous mass, most particularly when "trauma ruptures the capsule of an encapsulated tumor." 148 The presumption is against aggravation, however. A mirror-image theory posits that trauma sometimes retards growth of pre-existing tumors, the thought being that trauma may decrease blood flow to the cancerous area. Both theories remain quite speculative because cancer is an exceptionally variable disease and doctors possess no fine scale to clock its progression, accelerated or otherwise.

Without doubt, trauma's single most important cancer-related effect is to accelerate discovery and thus treatment. By the grand, cost-shifting logic that the Calabresians embrace, it is the trauma victim who usually owes the traumatizer for having supplied the beneficial bump that led to discovery of the disease. This idea is silly, of course, but perhaps less so than any of the

145. Ewing, 19 Archives of Pathology at 696 (cited in note 120).

146. Glover v Jackson Bush Co., 274 SC 644, 267 SE2d 77 (1980) (favorably quoting expert testimony at trial).

147. Ewing, 19 Archives of Pathology at 696 (cited in note 120).

148. See Monkman, Orwoll \& Ivins, 49 Mayo Clinic Proceedings at 161 (cited in note 94). 
countless other twists of science and logic by which insurers are regularly ordered to send checks in the other direction.

\section{G. 1962}

After years of floundering in the junk-science morass of traumatic cancer, judges slowly abandoned sequence-of-events logic, turned away from the sympathetic speculations of family doctors, and struggled on to the higher and firmer ground of epidemiology and medical science. Eventually, the change of heart among appellate judges was communicated back down to trial judges and worker's compensation boards, and traumatic cancer went into almost complete remission.

What became apparent, in the end, was that the disease had for years been nourished by judges themselves. Mainstream scientists had been saying so all along. "The cancerigenic potentialities of mechanical trauma would probably have long since ceased to stimulate any significant amount of scientific interest," wrote one weary commentator in 1954, "were it not for the fact that so many claims for compensation are filed each year." 149 Traumatic cancer would have been "relegated to limbo" far sooner, concluded the Mayo Clinic review twenty years later, but for "lawyers constantly keeping the question alive."'150

It is fair to say that the final cure for traumatic cancer was discovered where the disease had first originated: in court. A prescient article published in the New York Journal of Medicine in $1962^{151}$ suggested that traumatic cancer could be cured only by substitution: lawyers would have to be given some other cause of cancer to pursue. "[I]f the truth is that single injury cannot cause a malignant tumor, we see little hope in the present imperfect state of science and society of ever establishing such a fact to the satisfaction of everyone," the article concluded. ${ }^{152}$ "It may be that the relationship of trauma to cancer will be explained not by experiments designed to study this specific problem, but rather by an overwhelming clarification of the etiologies of malignant conditions that will appear with continuing basic cancer research."'153

This was a great insight. For nonscientists, no strictly negative proofs were ever going to suffice. Some other explanation for cancer would have to grip the legal imagination before traumatic cancer claims would be abandoned entirely. Perhaps the new explanation would be a better one, an "overwhelming clarification" of the real causes of cancer. Or perhaps something less solid would suffice.

149. See, for example, Alan Richards Moritz, Pathology of Trauma 116 (Lea \& Febiger, 2d ed 1954); see also Theodore J. Curphey, Trauma and Tumours, 1 J Forensic Sci 27 (1956).

150. Monkman, Orwoll \& Ivins, 49 Mayo Clinic Proceedings at 162 (cited in note 94).

151. Stoll \& Crissey, NY State J Med 496 (cited in note 46).

152. Id at 499 .

153. Id. 
That same year, Rachel Carson published The Silent Spring, ${ }^{154}$ a pathbreaking book on the effects of pesticides on birds and wildlife. Dr. Theron G. Randolph, an obscure medical eccentric, published his most important work that same year, Human Ecology and Susceptibility to the Chemical Environment. ${ }^{155}$

\section{III}

\section{Cerebral Palsy}

The tragedy was characteristically devastating. Alena D. weighed in two pounds nine ounces when she was born ten weeks premature on June 14, 1978 , in a breech delivery. By 1984 , she weighed only thirty-one pounds. She could not walk, crawl, or even raise her head for more than a few seconds without help. Every joint in her body had to be massaged daily to prevent stiffening. She seemed destined to remain incontinent and in a wheelchair for life. Alena had severe cerebral palsy.

Her parents sued the Medical College of Pennsylvania and three doctors who had assisted in Alena's complicated delivery. A breech birth and improper oxygen levels, the lawyers contended, had caused the devastating problems. They demanded $\$ 5$ million in compensation. ${ }^{156}$ The doctors answered that they had done everything in their power to help the child. The trial, before a Delaware County jury, lasted a month. The jury retired to deliberate, at which point the defendants offered the parents $\$ 2.2$ million in settlement. The offer was refused. Hours later the jury returned a verdict for the defense.

Births like Alena's, though profoundly shocking and unexpected, are also, paradoxically, a routine part of the human condition. There are countless other children like her. At least four thousand children are born with cerebral palsy every year. ${ }^{157}$

What causes the affliction? Is cerebral palsy acquired at birth, or is that just when it is first revealed? These questions have long been the subject of scientific speculation. Two centuries ago, a leading English physician noted that "in lingering labours when the head of the child hath been in the pelvis, so that the bones ride over one another, and the shape is preternaturally lengthened, the brain is frequently so much compressed that violent convulsions ensue before or soon after delivery to the danger, and ofttimes the destruction of the child."158 In 1861, William John Little, an orthopedic surgeon, concluded that cerebral palsy was caused primarily by trauma and

154. Rachel Carson, The Silent Spring (Fawcett, 1962).

155. Theron G. Randolph, Human Ecology and Susceptibility to the Chemical Environment (Charles C. Thomas, 1962).

156. Couple Loses Suit After Turning Down \$2.2 Million Settiement, The Associated Press (NEXIS, June $21,1984)$.

157. See Karin B. Nelson, What Proportion of Ceribral Palsy is Related to Birth Asphyxia?. J Pediatrics 112, 572 (April 1988); telephone interview with Dr. Leon Sternfeld, medical director of the United Cerebral Palsy Research and Education Foundation, April 26, 1990.

158. Quoted in Peter J. Schwartz, Birth Injuries of the Newborn 98 (Karger, 1961). 
other stresses during labor and delivery. ${ }^{159}$ Others later maintained that "adverse events during labor and delivery, particularly asphyxia and difficult birth," were the main causes. ${ }^{160}$

For over a century, many physicians agreed. Delivery was thought to be "an especially treacherous time for the fetus." 161 In 1951, two eminent physicians suggested that complications in delivery led to a range of brain injuries, with the most serious causing the child to be stillborn, the somewhat less serious resulting in such things as cerebral palsy. ${ }^{162}$ Trauma could cause birth defects like cerebral palsy, just as it could cause cancer. It seemed plausible enough.

\section{A. In Pursuit}

For personal-injury lawyers, tragedy is always opportunity. A lifetime of institutional care is breathtakingly expensive; if there is to be talk of legal damages, negotiations are likely to begin at $\$ 1$ million and go up from there. Everyone on the scene, in both clinic and court, will be overwhelmed with sympathy for the child and family. Modern medical science compounds the problem by reason of its very successes. Obstetricians have become so skilled at saving babies that their failures appear all the more shocking and unacceptable.

Beginning in the 1970s and accelerating through the 1930s, plaintiffs' lawyers pursued cerebral palsy cases quite vigorously. They relied on two quite distinct branches of the birth-trauma theory. Some emphasized physical trauma during delivery. Everyone is against traumatizing babies, and we all know why motorcyclists are supposed to wear helmets. Others emphasized asphyxia. The baby had been delivered too slowly, the delay had caused suffocation, and everyone knows that oxygen deprivation can destroy the brain.

Details varied from case to case. One mother successfully blamed her son's cerebral palsy on trauma caused by her fall at work shortly before his birth. ${ }^{163}$ When forceps were still widely used, they proved to be an especially popular target. Drugs like Pitocin, which is used to stimulate labor, were blamed; one mother recovered $\$ 7.5$ million on the theory that Pitocin caused unusually strong contractions, which were said to have injured the infant's

159. William J. Little, On the Infuence of Abnomal Parturition, Difficult Labour, Premature Births, and Asphyxia Neonatorum on the Mental and Physical Condition of the Child, Especially in Relation to Deformities, 3 Transactions of the Obstetrical Society of London 293 (1861); see also Nigel Paneth, Birth and the Origins of Cerebral Palsy, 315 New Eng J Med 124 (July 10, 1986).

160. See James R. Shields \& Barry S. Schifrin, Perinatal Antecedents of Cerebral Palsy, 71 Obstetrics \& Gynecology 899. 902 (June 1988); see also Mortimer G. Rosen, Factors During Labor and Delizery that Influence Brain Disorders, in John M. Freeman, ed, Prenalal and Perinatal Factors Associated with Brain Disorders 237 (US Dept Health \& Human Services, April 1985).

161. Roger Freeman, Intrapartum Fetal Monitoring-4 Disappointing Siory, 322 New Eng J Med 625 (March 1, 1990).

162. Abraham M. Lilienfeld \& Elizabeth Parkhurst, A Study of the Association of Factors of Pregnancy and Parturition with the Development of Cerebral Palsy: A Preliminary Report, 53 Am J Hygiene 262 (1951).

163. See Robin Berliner \& Mary-Agnes Bornhoeft, Medical Malpractice, Manhattan Lawyer 23 (Jan 19-25, 1988). 
brain. ${ }^{164}$ Asphyxia claims generally involved almost diametrically opposite charges, emphasizing not the abrupt violence of the birth but rather its unhurried slowness. The infant's umbilical cord was compressed, or the placenta was detached or deteriorating, or anesthetics administered to relieve the mother's pain had prolonged labor. One way or another, the birth was either too quick (and concomitantly violent) or too leisurely (and therefore suffocating).

The courtroom timing standards for delivering babies became exquisitely fine. ${ }^{165}$ One doctor was blamed for failing to induce labor, as was a second, but a third was blamed for inducing premature labor, as was a fourth. One doctor was faulted for using labor-stimulating Pitocin when it supposedly was not needed; another for failing to perform a caesarean when Pitocin was used; yet another for administering Pitocin early in labor but then administering an anesthetic that tends to counteract Pitocin's effect. Why, after all, would a doctor waste time relieving the mother's pain when there was a baby to deliver?

While few obstetricians cheered on the lawyers, many were inclined to agree that cerebral palsy might well be something they could beat, given enough information and skill at the time of delivery. Many-perhaps the most conscientious ones most especially-craved better understanding of how medicine itself might sometimes be the cause of great harm. What doctors needed, or so some sincerely believed, was a better way to detect signs of trouble during delivery before trouble turned into disaster.

In 1972, the electronic fetal monitor arrived on the medical scene. Electronic fetal monitoring ("EFM") involves inserting a sensor through the cervix, attaching it to the baby's head in the early stages of labor, and then tracing out the infant's heartbeat and the mother's contractions on a long paper chart. Many doctors welcomed EFM with high optimism. It was thought to be "a medical breakthrough that could reduce the incidence of cerebral palsy, stillbirth and infant death." 166 "[H]opeful that closer surveillance of labor would lower the number of handicapped infants," obstetricians hailed EFM and extolled its virtues in respected medical journals. ${ }^{167}$ By reading the heart monitors, the doctor would be able to tell when an infant was in "distress." When it was, doctors would perform caesarean sections, and trauma or suffocation would be prevented. One way or another, doctors would intervene promptly. Two pieces of fairly simple

164. See Bernard Cullen, United Press International (NEXIS, May 28, 1982).

165. See, for example, Dena Kleiman, Malpractice Suit Gives Millions But Not Hope, NY Times Bl col 5 (March 1 1, 1985); Maria L. La Ganga, Traumatic-births Suit Ends In \$6.8-million Settlement, LA Times I col 1 (Sept 20, 1985).

166. Tamar Lewin, Despite Criticism, Fetal Monitors Are Likely to Remain in Wide Use, NY Times 24 col 3 (March 27, 1988).

167. Paneth, 315 New Eng J Med at 126 (cited in note 159); see also Institute of Medicine, 1 Medical Professional Liability and the Delivery of Obstetrical Care 78 (Natl Acad Press, 1989); Edward J. Quilligan \& Richard H. Paul, Fetal Monitoring: Is It Worth It?, 45 Obstetrics \& Gynecology 96 (1976). 
technology, a monitor and a scalpel, would significantly reduce the tragedy of cerebral palsy.

The optimism ran so high that EFM became widely used before anyone began methodically to test its efficacy. ${ }^{168}$ By the end of 1972, more than 1,000 EFM systems were in use in the United States. Five years later, more than 70 percent of physicians believed that births should be electronically monitored. By 1986 in New York, 75 percent in fact were. ${ }^{169}$ Numerous reports appeared during the early and middle 1970s, which indicated that "electronically monitored fetuses did much better than those undergoing [manual monitoring] during birth." 170 These reports, however, were entirely anecdotal, a grab bag of impression, hunch, and hope.

If EFM raised the hopes of doctors in the delivery room, it most assuredly raised the hopes of lawyers in the courtroom. Before EFM, obstetricians had monitored fetal distress with a stethoscope. In court a year or two later, all the speculation from the plaintiff's expert effectively could be countered by the defending doctor's simple, confident recollection that there had been no evident fetal distress, and therefore no cause to either slow or accelerate delivery. EFM changed everything: it supplied a paper chart for the record. After-the-fact speculation could now focus on something much more concrete than the obstetrician's undoubtedly self-serving recollections. Another doctor could now deliver the baby a second time, in court. More successfully, of course.

In increasing numbers, juries began to agree that cerebral palsy might well have been averted if only the obstetrician had used or understood the EFM trace properly. ${ }^{171}$ The rural hospital (for example) did not even own a $\$ 10,000$ fetal monitor; this possibly explains the child's cerebral palsy. Or perhaps the problem was a monitor that was misused or malfunctioned. Had EFM been properly conducted, and the results correctly interpreted, a competent obstetrician would of course have hustled the mother into the delivery room and grabbed for a knife. ${ }^{172}$ There is no disputing that a good surgeon with a sharp knife can do in a matter of minutes what the most athletic woman's abdominal muscles normally require hours to complete. If a

168. See Institute of Medicine, 1 Medical Professional Liability at 78 (cited in note 167).

169. Id at 77 .

170. Freeman, 322 New Eng J Med at 624-25 (cited in note 161).

171. See, for example, John Spano, Young Cerebral Palsy Victim Progresses; Malpractice Suit Setlled In Hospital Brain Damage Case, LA Times 8 col 1 (June 12, 1987).

A 1987 national survey of gynecologists and obstetricians by the American College of Obstetricians and Gynecologists reveals that $45.8 \%$ of obstetrical claims filed involved EFM use. Opinion Research Corporation, Professional Liability and its Effects: Report of a 1987 Survey of ACOG's Membership 16, Table 2 (March 1, 1988). The question in the survey, however, was rather ambiguous. Doctors were asked about legal claims they had experienced, and then asked "[w]hich of the following items ... apply to this claim?" The list included forceps, breech presentation, EFM, and so on. It is unclear from the study whether obstetricians would have understood this to mean that EFM was actually involved in the litigation, or simply used in the delivery.

172. See, for example, Low v United States, 795 F2d 466 (5th Cir 1986); Laurie Garrett, Care Bow's to Costs; Insurance Rates Are Driving Obstetricians from the Delivery Room in Record Numbers, Newsday Discovery sec at 1 (July 12, 1988). 
caesarean was performed, it should have been performed sooner. ${ }^{173}$ The stories had not changed much, but the reams of new paper could now make them seem very much more immediate and plausible.

On one significant count, however, the doctors' early enthusiasm for EFM diverged sharply from the lawyers'. EFM, it soon became apparent, was imprecise. "Fetal distress" is itself a very fuzzy term, if only because some quite variable degree of distress is normal when undergoing the first and most traumatic of all partings in the human experience. Nature seems to have deliberately designed the hydraulics to be stressful, partly to allow the infant as long a time as possible in the shelter of the womb, partly to help clear the infant's lungs when time finally runs out. In any event, obstetricians discovered that they very often disagreed on just what EFM recordings meant. ${ }^{174}$ For obvious reasons, this unsettled the doctors. For reasons equally obvious, it delighted the lawyers.

It turned out that the lawyers, and the doctors they were able to hire, had much less trouble reading EFM charts than doctors generally. "It's unbelievable, it's so clear-cut," exclaimed one "ecstatic" lawyer when he first got hold of Alissa G.'s medical records. ${ }^{175}$ Ten days after her due date, Alissa's mother had gone in for a first EFM trace. Labor began the next day, producing a second trip to the hospital, a second EFM trace, and a second return home to wait for further dilation. On the third visit, Alissa was born, apparently without complication, but with cerebral palsy. The lawyer, unlike the several doctors who had attended Alissa's mother at the time, immediately discerned "[s]ome irregularity" in the first EFM trace, and plain signs of "distress" in the second. Best of all, the first trace had been recorded by a doctor inexperienced in using the monitor. Delayed labor, the plaintiffs claimed, had allowed disintegration of the placenta, causing oxygen deprivation. A competent EFM interpretation would have led to induced labor or a caesarean, and Alissa would be a normal child today. The insurance companies settled for $\$ 2.5$ million. ${ }^{176}$

Such formulas could be rolled out a thousand times: the attending physician faced obvious "fetal distress" yet failed to detect it; the doctors and nurses "failed to interpret fetal monitor readings showing the fetus in distress"; 177 they failed "to accurately analyze and act upon warning signs indicated by the fetal heart tone monitor";178 they overlooked significant distress for an hour and a half during labor;" 79 they failed "to properly read a

173. See, for example, Nemmers $v$ United States, 612 F Supp 928 (CD Ill 1985), judgment vacated by 795 F2d 628 (7th Cir 1986).

174. Nancy K. Rhoden, The Judge in the Delivery Room: The Emergence of Court-Ordered Cesareans, 74 Calif L.Rev 1951, 2016 (1986).

175. See Kleiman, NY Times Bl col 5 (cited in note 165).

176. Id.

177. \$3.2 Million Negligence Award, The Associated Press (NEXIS, July 22, 1988).

178. PR Newswire (NEXIS, Dec 10, 1986).

179. \$2.1 Million Awarded in Birth of Brain-Damaged Boy, The Associated Press (NEXIS, Oct 10, 1986). 
fetal heart monitor during the six hours of labor"; 180 or they "failed to notice a fetal heart monitor... showed the unborn infant was not getting an adequate oxygen supply." 181 The doctor on the witness stand understands the critically fine variables at work far better than the doctor who actually delivered the baby. Just a wee bit faster with the knife, or easier on the forceps, or lighter (or heavier) on the Pitocin or the labor-slowing anesthetic, and things would undoubtedly have worked out better. The beauty of selling techno-magic elixirs in court is that no one even has to produce the bottle for close examination. An earlier caesarean would have done the trick. How much earlier? Well, earlier. EFM would have revealed fetal distress. And just what is distress? Well, a good doctor like me knows it when he sees it.

Today, this line of attack has become one of the most spectacularly lucrative enterprises that lawyers know, quite possibly the single largest revenue raiser in all of medical malpractice. About 4 million babies are born healthy every year. Ignore them. Some 4,000 babies a year are born with cerebral palsy. Ignore most of them too. But 400 (say) of those had a complicated delivery. These are the cases most likely to arrive in court. And there, the facts are reviewed chronologically, so that the jury sees the undisputed trauma first, the disputed negligence second, the undisputed cerebral palsy third. It is a perfect set-up for misinterpreting sequence as cause. That set-up, litigated a mere forty times with a one-in-two success rate, can yield a small law firm $\$ 50$ million or so, on an upfront investment for expert witness fees and administrative costs of maybe $\$ 5$ million at most.

The promise of such profits inevitably attracts some shady characters. One former New York City lawyer confessed in grand jury proceedings that he had earned $\$ 1.5$ million selling about one hundred cerebral palsy cases to other New York City firms between 1979 and 1982. How had he come to own them in the first place? He bought them from staff employees at cerebral palsy rehabilitation centers, who at $\$ 2,000$ a shot turned over confidential files of patients who were then solicited to bring malpractice suits. Twenty-one New York law firms were named as buyers of the information. ${ }^{182}$ Another part of this brokering service involved preparing compliant expert witnesses, who were normally paid $\$ 5,000$ per case. This story may be atypically sordid, but the general method is standard. The victim is located first; then the lawyer and a well-paid expert root about for a cause plausible enough to pitch to a jury.

In every lawsuit the stakes are huge and the outcome highly unpredictable. Recall the case of Alena D., whom we visited at the beginning of this chapter. The distraught parents turned down a $\$ 2.2$ million settlement offer when it was there for the taking. The insurance company almost gave away what was its to keep. An expert once suggested that the classification of "low-risk"

180. United Press International (NEXIS, March 19, 1984).

181. The Associated Press (NEXIS, April 30, 1981).

182. Selwyn Raab, Former Lawyer Says He Paid Off Judges In Medical Lawsuits, NY Times Al col 6 (March 7, 1985). 
pregnancies is best made "by exclusion, three months after birth." $183 \mathrm{He}$ might more accurately have said, three years later, just minutes after the jury returns to the courtroom. Few smart players on either side of the aisle dare to wait quite so long, which is why so many cerebral palsy cases are settled on the eve of trial. Defendants fear runaway sympathy. Plaintiffs fear plodding science. No one knows which will carry today's jury, and the uncertainty is simply more than either side can stand. ${ }^{184}$

Trials, if defendants dare wait for them, proceed like a techno-thriller. There is a rich veneer of pseudo-scientific detail about trauma and oxygen levels, monitors, labor-enhancing drugs, and labor slowing anesthetics. The gadgets and props all heighten the tension that something very high-tech is about to go horribly wrong. The detail can be gripping. Let me take you back to the delivery room, ladies and gentlemen. The mother is exhausted. EFM reveals an infant in distress. And yet the doctor does not act. Look! A child's brain is disintegrating before your eyes! Do something! A good lawyer can direct this kind of production like a Hitchcock thriller, with all the agonizing suspense of a murderer, knife in hand, creeping up on the unsuspecting young woman in the shower. The only difference being that in cerebral palsy cases the trick is to get the audience screaming for more knife rather than less. Many audiences do indeed scream. But the scientific story is about as real as celluloid.

\section{B. Causes}

Most cerebral-palsy babies, it in fact appears, are doomed long before an obstetrician comes near them. More than half who display at least one sign of asphyxia at birth also exhibit some more important risk factor, like congenital malformation, low birth weight, or microcephaly-problems completely beyond the control of modern obstetrical science. We know this from (among numerous other scientifically solid sources) a major epidemiological study by the National Institutes of Health, published in the New England Journal of Medicine in July 1986. ${ }^{185}$ That study, the largest ever of its kind, surveyed some 54,000 pregnancies between 1959 and 1966 at twelve hospitals. The results of a study this size are about as solid and certain as medical science ever supplies.

So is the baby that has been pummeled about the head with forceps, or expelled from the womb with undue force, more likely to be afflicted with cerebral palsy? Generations of doctors have subscribed to the theory. Generations of doctors have been wrong. Forceps, rough delivery, trauma of any kind at birth, just do not cause cerebral palsy in any significant degree.

183. Barry Schifrin, Legal Implications of EFM (paper given at conference on medicolegal issues in obstetrics in New York, Oct 3, 1985).

184. Compare Richard P. Blow, Trial by Error, Regardie's 66-83 (April 1989).

185. Karin B. Nelson \& Jonas H. Ellenberg, Antecedents of Cerebral Palsy: Multivariate Analysis of Risk, 315 New Eng J Med 81 (July 10, 1986). 
Breech delivery, which commonly involves a pretty violent exit if a caesarean is not performed, hardly correlates with cerebral palsy at all. ${ }^{186}$

What about oxygen? Yes, it is possible for asphyxia to cause cerebral palsy. But only if the asphyxia is exceptionally severe and prolonged. Newborn mammals have an astonishing resilience to oxygen deprivation; a newborn's fetal hemoglobin allows it to survive vastly more severe oxygen shortages than it will be able to even a few weeks after birth. In fact, the level of oxygen deprivation necessary to produce severe brain damage in a newborn is close to the level that is lethal; ${ }^{187}$ most newborn infants subjected even to severe, prolonged asphyxia recover and suffer little or no neurological damage. ${ }^{188}$ So asphyxia does not explain any significant fraction of cerebral palsy infants. The duration of labor shows no significant correlation with the incidence of cerebral palsy. Nor does low placental weight. Nor a low fetal heart rate-the one thing EFM may help flag.

What then are the important causes of cerebral palsy? No one knows. Prematurity does not correlate significantly with cerebral palsy. Nor does drug use by mothers, nor family history. An umbilical cord chronically pinched during pregnancy may be a factor. Genetic factors may play some role. Chronic fetal distress-not during delivery but sustained throughout pregnancy-may be a symptom of trouble, though not characterizable as a cause. Somewhat more important is a mother's history of seizures. " $[\mathrm{T}] \mathrm{he}$ single most prominent predictor of cerebral palsy [is] mental retardation in the mother." But no single factor plays a role significant enough to suggest it as "the cause" of the disease. And no factor related to labor and delivery is associated with more than 2 percent of the risk. ${ }^{189}$ Cerebral-palsy risk factors usually overlap, making it all but impossible to say which (if any) are causes, which are merely effects. In short, " $[t]$ he evidence is very convincing that complications during labor and delivery are not responsible for the meaningful proportion of cases of cerebral palsy." 190 "We probably do not know what causes most cases."191

The best guess we have today is that cerebral palsy is almost always caused by events that began long before delivery. ${ }^{192}$ In 1986, a noted pathologist

186. Breech positioning (as distinguished from breech delivery) is associated with fetal problems, but is not a matter under the obstetrician's control.

187. John M. Freeman \& Karin B. Nelson, Intrapartum Asphyxia and Cerebral Palsy, 82 Pediatrics 240 (Aug 1988).

188. See, for example, Ronald E. Meyers, Two Patterns of Perinatal Brain Damage and Their Conditions of Occurrence, 112 Am J Obstetrics \& Gynecology 246 (1972); Gerald M. Fenichel, Hypoxic-ischemic Encephalopathy in the Newborn, 40 Archives of Neurology 261 (1983); Hilary Scott, Outcome of Very Severe Birth Asphyxia, 51 Archives of Disease in Children 712 (1976).

189. Nelson \& Ellenberg, 315 New Eng J Med at 83 (cited in note 185).

190. United Press International, Birth Trauma is Found Minor Fact in Palsy, NY Times A20 col 5 (July 10, 1986), quoting Jonas Ellenberg.

191. Nelson \& Ellenberg, 315 New Eng J Med at 85 (cited in note 185); see also William H. Kitchen, et al, Cerebral Palsy in Very Low Birthweight Infants Surviving to Two Years with Modern Perinatal Intensive Caie. 4 Am J Perinatology 29-35 (1987).

192. See, for example, Ronald S. Illingworth, Why Blame the Obstetrician? A Review, 1 British Med J 797-801 (1979); Thomas J. Garite, et al, Fetal Heart Rate Patterns and Fetal Distress in Fetuses with 
suggested that oxygen deprivation plays an important role only when it occurs in the late second or early third trimester. ${ }^{193}$ Other researchers surmise that a chronically pinched umbilical cord during pregnancy may be important. ${ }^{194}$ Still others point to fetal infections and placental problems early in pregnancy. ${ }^{195}$ Congenital or early-pregnancy factors may, of course, produce a host of different problems later on, problems that first become evident at the time of delivery. Low birth weight correlates with cerebral palsy, but might reflect placental problems from months earlier. Oxygen deficiency, a minor though often vastly overestimated risk factor, may likewise be a reflection of earlier problems, rather than a cause of later cerebral palsy. In short, "the anomaly of the birth process, rather than being the causal etiologic factor, may itself be the consequence of the real prenatal etiology." 196 Sigmund Freud, a neurologist in his first career, wrote those words about cerebral palsy in 1897 . Almost a century later, they still accurately summarize the best medical guess we have.

If causes at the time of delivery have little or no effect on the risk, and we do not know where the main causes lie, obstetricians cannot prevent cerebral palsy. One would never know it from reading about the lawsuits, but the scientific consenus on that point is now quite solid. One medical study after the next has reached the same conclusion. " $[\mathrm{N}] \mathrm{o}$ foreseeable single intervention is likely to prevent a large proportion of cerebral palsy;" 197 it is "naive ... to assume that cerebral palsy derives from a single cause, or that it is amenable to a single form of intervention;" 198 blaming events that occur during delivery "is unjust and represents a failure to look behind the events of birth."199

How then can EFM prevent cerebral palsy? It cannot. ${ }^{200}$ Indeed, EFM is such an imprecise tool that it cannot do much of anything, except economize on the cost of nurses. In one very revealing study, twelve national EFM experts interpreted fourteen abnormal heart patterns. On average, two physicians disagreed one time in three in classifying the patterns as "innocuous," "nonreassuring," or "ominous."201 They disagreed almost one time in three as to whether to continue monitoring or to deliver immediately. Supplementing EFM with scalp blood-sampling results increased the levels of

\footnotetext{
Congenital Anomalies, 53 Obstetrics \& Gynecology 716-20 (1979); Tim J. Peters, et al, Delayed Onset of Regular Respiration and Subsequent Development, 9 Early Hum Dev 225 (1984).

193. Abraham Towbin, Obstetric Malpractice Litigation: The Pathologist's Point of View, $155 \mathrm{Am} \mathrm{J}$ Obstetrics \& Gynecology 927 (1986).

194. James F. Clapp III, et al, Brain Damage after Intermittent Partial Cord Occlusion in the Chronically Instrumented Fetal Lamb, 159 Am J Obstetrics \& Gynecology 504-09 (1988).

195. Raul Bejar, et al, Antenatal Origin of Neurologic Damage in Newborn Infants, 159 Am J Obstetrics \& Gynecology 362 (1988).

196. Sigmund Freud, Infantile Cerebral Paralysis 142 (L. A. Russin, trans., U Miami Press, 1968).

197. Nelson \& Ellenberg, 315 New Eng J Med at 86 (cited in note 185).

198. Shields \& Schifrin, 71 Obstetrics \& Gynecology at 903 (cited in note 160).

199. Illingworth, 1 British Med J at 797 (cited in note 192).

200. Institute of Medicine, 1 Medical Professional Liability at 79-80 (cited in note 167).

201. Alan B. Cohen, Henry Klapholz \& Mark S. Thompson, Electronic Fetal Monitoring and Clinical Practice, 2 Med Decision Making 79, 84-91 (1982).
} 
disagreement. These cpntradictory analyses were from some of the nation's top EFM experts; a much wider range of disagreement can be expected from randomly drawn obstetricians. Small wonder, then, that EFM provides no measurable bottom line benefits. As early as 1976, a team of researchers found that EFM was no better than stethoscope monitoring. ${ }^{202}$ Since then, nine randomized clinical trials have been performed in Australia, Denmark, Ireland, Scotland, and the United States. Not one study has found that EFM benefits infants, ${ }^{203}$ even in "high risk" deliveries. ${ }^{204}$ As a report by the Institute of Medicine concluded in 1989, " $[t]$ he incidence of cerebral palsy, still popularly and erroneously believed by many to be the result of fetal asphyxia, has not been reduced by EFM.,"205

The crowning blow came in March 1990, when American and Canadian researchers released the results of the most recent and largest EFM study, based on six years of data. Not only did EFM fail to improve premature infants' neurological development, but "in most comparisons the results of [stethoscope monitoring] were actually superior."206 Infants monitored with a stethoscope performed consistently higher on mental and psychomotor development tests than EFM infants. Stethoscope-monitored births on average took less time than electronically-monitored births. Astoundingly, EFM-children ran a 2.9 times greater risk of developing cerebral palsy than stethoscope-monitored children. That number, however, is in all likelihood a pure statistical fluke.

So the vaunted fetal monitor, the first card, the trump card, quite often the only card, in the cerebral-palsy litigation deck, is a joker. It delivers wonderful results for lawyers, but not for anyone else. The wonder is that some trial lawyer is not now waving the Canadian-American study under the noses of some jury, demanding to know why this brain-destroying EFM technology had ever been allowed near the unfortunate child.

202. Albert D. Haverkamp, et al, The Evaluation of Continuous Fetal Heart Rate Monitoring in High-risk Pregnancy, 125 Am J Obstetrics \& Gynecology 310 (1976).

203. Stephen B. Thacker, The Impact of Technology Assessment and Medical Malpractice on the Diffusion of Medical Technologies: The Case of Electronic Felal Monitoring, in Victoria P. Rostow \& Roger J. Bulger, eds, 2 Medical Professional Liability and the Delivery of Obstetrical Care: An Interdisciplinary Review 9 (Natl Acad Press, 1989).

204. Kenneth S Leveno, et al, A Prospective Comparison of Selective and Universal Electronic Fetal Monitoring in 34,995 Pregnancies, 315 New Eng J Med 615-19 (1986); David A. Luthy, et al, $A$ Randomized Trial of Electronic Fetal Monitoring in Preterm Labor, 69 Obstetrics \& Gynecology 687 (1987).

205. Institute of Medicine, 1 Medical Professional Liability at 81.82 (cited in note 167). Critics of the trials have maintained that the samples were too small to produce statistically significant results. $H$. David Banta \& Stephen B. Thacker, Assessing the Costs and Benefits of Electronic Fetal Monitoring, 34 Obstetrics \& Gynecology Surv 627, 633 (1979); Roger V. Freeman \& Thomas J. Garite, Fetal Heart Rate Monitoring 168 (Williams \& Wilkins, 1981). Others have argued that "[ $\mathrm{t}] \mathrm{he}$ very size of the required groups casts doubt on the need for universal use of EFM, since obviously very low incidence problems are involved." See Albert Haverkamp, et al, A Controlled Trial of the Differential Effects of Intrapartum Fetal Monitoring, 134 Am J Obstetrics \& Gynecology 399-400 (1979).

206. Kirkwood K. Shy, et al, Effect of Electronic Fetal-Heart-Rate Monitoring, As Compared with Periodic Auscultation, on the Neurologic Development of Premature Infants, 322 New Eng J Med 588, 592 (March 1, 1990). 


\section{Dangerous Therapies}

While it is inconceivable that EFM directly causes cerebral palsy, it is more than conceivable that the indiscriminate use of EFM impelled by litigation has caused much real harm. EFM tends to flag problems that are not. Fear of liability then induces drastic intervention that does no good except in court. Many doctors have proved quite willing to be induced. With a caesarean, after all, the mother is quiet, the baby is lifted quickly through a large passage rather than extruded slowly through a small one, the fee is higher; all in all, from the right side of the knife, it really does look more genteel and efficient. Not surprisingly then, the rise of EFM has been accompanied by a dramatic increase in the rate of caesareans. ${ }^{207}$ Caesarean delivery accounted for 5 percent of all deliveries in 1970; today, the United States has the highest caesarean rate in the world, roughly 25 percent of all births. ${ }^{208}$ Caesareans then breed more caesareans; another cherished, if medically dubious, rule of thumb maintains that "once a caesarean, always a caesarean," so that the caesarean child's younger siblings are delivered by knife too. If the current trends continue, half of all babies born in the United States will be delivered in this way at the turn of the century.

And what of it? Caesareans are also twice as expensive as normal delivery, already costing $\$ 3$ billion a year. ${ }^{209}$ Infants born by caesarean generally score lower on post-natal tests; vaginal delivery may in fact help clear lungs and stimulate breathing. And caesareans pose real risks to the mother. A caesarean birth-which is, of course, fairly serious abdominal surgery-is two to four times more likely to kill the mother. ${ }^{210}$ Fearful of lawsuits if they do not intervene, some doctors have even begun to seek court orders to force caesareans on unwilling mothers carrying infants judged to be "in distress." 211

If plaintiffs' lawyers have willingly (and very profitably) become parties to this injustice, so have quite a few doctors who are retained as expert witnesses. Some testify for the same financial reasons as the lawyers, and many testify in the sincere but mistaken belief that they know more than they really do. Is this to say that many doctors are bad scientists? Yes. Most are practitioners, not scientists at all. While good doctors learn from science, stay abreast of its developments, and maintain a strong faith in the scientific method, some less skilled́ ones do not. Like all other clinicians, obstetricians are constantly exposed to biased evidence that encourages false inference.

207. According to the National Institutes of Health, 10-15\% of the ceasarean rate increase resulted from increased diagnoses of fetal distress. NIH, 51 Cesarean Childbirth: Report Of $A$ Consensus Development Conference 14-17 (1981) (US Dept of Health \& Human Servs Pub No 82-2067).

208. See Associated Press, Risky Business: Delivering Babies, The Washington Times F2 (Oct 20. 1989) (editorial).

209. See Anne Merewood. Surgical births: Are physicians performing unnecessary caesareans?, Chicago Tribune C3 $\$ 6$ (May 7, 1989) (reporting that halving the cesarean rate would save $\$ 1.5$ billion annually); see also Garrett, Newsday, Discovery sec at 1 (cited in note 172) (comparing 1986 cost of vaginal delivery $(\$ 2,900)$ with cost of delivery by cesarean section $(\$ 5,270)$ ).

210. See Merewood, Chicago Tribune at C3 (cited in note 209).

211. Rhoden, 74 Calif L Rev at 1951, 2016 (cited in note 174). 
Many are seduced, some so completely that they are then willing to testify to all sorts of things under oath. Heroic rescues are always easy to imagine. Things that exist only in the imagination can never, of course, be definitively disproved.

EFM makes the imagining more vivid; it offers doctors a psychological crutch, a pseudo-scientific anchor in a turbulent sea of biological uncertainty, and gives them the appearance of control but not the actuality. The mainstream of the profession has recognized as much. In January 1988, a committee of the American College of Obstetricians and Gynecologists ("ACOG") recommended altering its longstanding policy in favor of EFM. ${ }^{212}$ Low-risk patients could be monitored by stethoscope, while high-risk patients could be monitored by EFM, stethoscope, or a combination of both. ${ }^{213}$ So far as medical science was concerned, the EFM saga is now over.

Today, most obstetricians are well aware of this. But few dare take the lead in changing their ways. Why should they? Lawyers have discovered in EFM the perfect technological wand to wave before juries. For all practical purposes, EFM has become the legally established standard for prudent care. Even most of the ACOG panel members conceded they would continue using EFM themselves. As the Institute of Medicine tersely noted, "the current professional liability climate supports the continued use of EFM, despite overwhelming evidence that it does not improve neonatal mortality and morbidity rates."214 What holds for EFM holds even more for caesareans. The woman given an unnecessary caesarean and delivered of a healthy baby is unlikely to sue. The "maxi-min strategy"215 - the strategy that focuses obsessively on the worst possible outcome and relies on the most extreme and interventionist (though ineffectual) methods in an attempt to prevent it-has become the only legally safe course in modern obstetrics.

Yes, once in a great number of times there really may be a case where a caesarean might help prevent cerebral palsy, or an obstetrician's incompetence may contribute to causing it. Perhaps some small fraction of that small fraction of deliveries produces a lawsuit that culminates in a welldeserved settlement or verdict. But for every one such case, there are dozens of baseless shakedowns. This statement can be made with high confidence, given the current state of medical science. We know there are many thousands of new cases of cerebral palsy a year. Exact numbers are impossible to come by, but only a tiny fraction of those culminate in successful lawsuits. There is no evidence-none whatsoever-that the cases that come to court have lined up at all consistently with cerebral-palsy causing malpractice beforehand. If they had, we would expect to see some positive effects on cerebral palsy rates. No such effects have ever been observed.

212. See Lewin, NY Times at $24 \mathrm{col} 3$ (cited in note 166).

213. Guidelines for Prenatal Care 67 (Am Acad Pediatrics and the Am College Obstetricians \& Gynecologists, 2d ed 1988) ("AAP Guidelines").

214. Institute of Medicine, 1 Medical Professional Liability at 81 (cited in note 167).

215. See Howard Brody \& James R. Thompson, The Maximin Strategy in Modern Obstetrics, $12 \mathrm{~J}$ Fam Practice 977 (1981). 
This is, indeed, the part of the story that jurists and legal academics have most inexcusably neglected to track. Obstetricians have capitulated to virtually every demand of the modern legal system. Birth trauma now occurs far less frequently than it used to. ${ }^{216}$ Forceps have almost disappeared. EFM, unknown in 1970, is now used in at least three quarters of all deliveries. Caesarean deliveries have increased five-fold. After two decades of highpriced help from their ranks, we may now ask the lawyers: just what have you achieved on the cerebral palsy front?

If the lawyers had been right, the cerebral palsy problem should by now be abating, and with it the lawsuits. Nothing of the sort has happened. With one modest exception unrelated to litigation, the cause and prevention of cerebral palsy remain mysterious. (The exception involves certain blood incompatibilities between mother and infant that today can be recognized and treated. ${ }^{217}$ ) Cerebral palsy is as common as ever, ${ }^{218}$ perhaps even rising slightly as more babies who once would have died now survive. ${ }^{219}$ There certainly is no firm evidence of any appreciable decrease in cerebral palsy in the past forty years. ${ }^{220}$ And though they are sued vastly more often, there is no evidence whatsoever that American obstetricians are performing any better than their foreign counterparts in other industrialized countries.

216. From the late fifties to the early seventies, the British Birth Survey reported substantial decreases in intracranial birth traumas. Albert E. Claireaux, Pathology of Perinatal Hypoxia, $30 \mathrm{~J}$ Clinical Pathology 142-48 (1977). Forceps use has nearly disappeared; in 1976-77, for example, only 5 percent of births in New York City and Cleveland involved forceps. Mortimer G. Rosen, Factors During Labor and Delivery that Influence Brain Disorders, in John M. Freeman, ed, Prenatal and Perinatal Factors Associated with Brain Disorders 238 (U.S. Dept Health \& Human Svcs, Pub Health Serv, Natl Inst Health, April 1985).

217. Some modest progress did come from the virtual elimination of one source of athetoid cerebral palsy, hyperbilirubinemia, caused by blood incompatibility between mother and infant or by newborn jaundice. Doctors now have effective means for dealing with these problems that they lacked 30 years ago.

218. "Despite earlier optimism that cerebral palsy was likely to disappear with the advent of improvements in obstetric and neonatal care, there has apparently been no consistent decrease in its frequency in the past decade or two." Nelson \& Ellenberg, 315 New Eng J Med at 1 (cited in note 185). See also Freeman \& Nelson, 82 Pediatrics at 240 (cited in note 187) (noting "little change in the frequency of cerebral palsy").

\section{As one observer reports:}

The most recent population surveys of cerebral palsy, however, do not demonstrate consistent evidence of a decline in prevalence since the era of the National Collaborative Perinatal Project, and some studies even show a rise ... . Neonatal intensive care now ensures the survival of a much higher proportion of asphyxiated infants of all weights. If these new survivors have a higher incidence of cerebral palsy than occurs in the general population, cerebral palsy might be expected to bear a stronger relation to indicators of asphyxia than was the case 20 years ago.

Paneth, 315 New Eng J Med at 125 (cited in note 159).

220. The best epidemiological guess we have is that in the last 40 years "there just has not been a change" in the cerebral-palsy rates. Conversation with Dr. Karin Nelson, May 15, '1990. Nelson emphasizes that the available data are "extremely soft," in part because cerebral palsy has never been consistently defined. Over the last fifteen years, fluctuations have occurred, but epidemiologists have detected no consistent trends in either direction. See also Nelson \& Ellenberg, 315 New Eng J Med at 124 (cited in note 185 ). 


\section{Lessons from Mt. Sinai}

American lawyers engaged in this kind of litigation, by contrast, perform better than lawyers anywhere else in the world. Invoking a simple gadget and a sharp knife, they have cashed in munificently on the cure half of scientific credulity. In an earlier day, the magic cures had to be sold to the patient himself, who might at least pause as he reached into his own pocket to pay for the elixir. Juries reach elsewhere, which may explain in part why selling such cures in court has proved vastly more remunerative.

This is not to suggest that plaintiffs always win. After an eight-day trial, nine years after the birth of one stillborn and one cerebral palsy twin, for example, both attending doctors were cleared by the jury. ${ }^{221}$ A Michigan jury exonerated both the doctors and the hospital in a different suit alleging failure to use EFM and undue delay in conducting a caesarean. ${ }^{222}$ Another obstetrician won summarily against charges of undue delay in treating oxygen deprivation. ${ }^{223}$ The defense won yet again in a case involving complicated labor and standard charges of fetal distress evident by EFM. ${ }^{224}$ A New Mexico jury absolved the obstetrician and the manufacturer of Pitocin of any blame in still another case, rejecting charges that too severe contractions cut off the infant's blood supply and that a caesarean was unduly delayed. ${ }^{225}$

Defendants do win a generous share of cases, but the outcome is always hugely uncertain. The defending doctor may present the icy statistics in mind-numbing detail, lining up bean counters to testify that links between birth complication and cerebral palsy are almost immeasurably weak. He may summon top-flight members of the College of Obstetricians to declare that fetal monitors have proved completely ineffectual in preventing cerebral palsy. But testify as they will, the other side has the huge psychological advantage of an incontinent child in a wheelchair. Yes, jurors, like scientists, may be able to sort out the facts notwithstanding sympathy, case-selection bias, and the powerful, intuitive instinct to view a vividly described sequence of events as cause and effect. But even trained scientists make the this-thenthat mistake so often that they force themselve to follow elaborate, rigorous protocols to protect against it, and no such protocols must be followed by self-styled experts on the witness stand. The system is not inherently biased or unreasonable, but in practice it is just highly random. And when the stakes are so high, randomness itself is the epitome of injustice.

Sadly, there is much that is still random in reproduction and obstetrics too. The medical profession has never been omniscient, nor is it ever likely to be. Doctors have made their share of mistakes in their too-hopeful pursuit of the

221. Poynter v Ratcliff, 874 F2d 219 (4th Cir 1989).

222. Wolak "Walczak, 125 Mich App 271, 335 NW2d 908 (1983). See also Lane v Skyline Family Medical Center, 363 NW2d 318 (Ct App Minn 1985).

223. Burciaga v St. John's Hospital, 232 Cal Rptr 75, 187 Cal App 3d 710 (1986).

224. See Tom Kapsidelis, Court Rules in Favor of Hospital, United Press International (NEXIS, April $5,1985)$.

225. Davila " Bodelson, 103 NM 243, 704 P2d 1119 (1985). 
causes of cerebral palsy. The legal system, however, positively distorted the science, and has made the mistakes all but impossible to correct. Far from accelerating the shift to better medicine, litigation has frozen in place unhelpful techno-fix, and contributed to the dis-education of medical practitioners. There is little doubt that the cumulative costs of this misdirected litigation are now measured in lost lives.

The serious pursuit of better medicine-which is to say, its pursuit outside the courtroom-now emphasizes less intervention, not more. "Do not just do something; stand there!" runs the new aphorism for obstetricians at Mt. Sinai Hospital in Chicago. ${ }^{226}$ What is this-insanity? Only so far as your legal adviser is concerned. From all other perspectives, it is better medicine. As documented by Stephen Meyers and Norbert Gleicher in the New England Journal of Medicine, caesareans at Mt. Sinai have declined over two years from 17.5 percent in 1985 to 11.5 percent in 1987 of all births, "without any apparent detrimental effect on either maternal or neonatal outcome."227 The use of medical instruments in delivery has declined too. "We learned to take a more "hands off approach towards our patients in labor," said Stephen Myers, one of the study's authors. "Sometimes it takes the most experienced and best judgment to know when not to do something." 228 One way of "reducing the rush" to unnecessary caesareans has been to rely more on midwives and nurse practitioners, as in Europe where far fewer caesareans are performed. Despite all these changes, which were made at real legal peril to the doctors who endorsed them, there has been no rise in complications for either mothers or infants.

IV

\section{Galileo's Revenge}

The ghost of Galileo still haunts the American courtroom. Let's not ostracize the "mini Galileo," pleads a plaintiff's lawyer; the legal system must be "capable of advancing." 229 Honor the expert "at the edges of the bell curve," advises a peripatetic expert on the imaginary disease of "chemical AIDS," "as was Galileo and as are other people at the frontiers of medicine or science." 230 Yes, we all know that these people have most unusual views on the causes of disease. But as the judge prepares to the plaintiff out of court, cancer, birth defect, or cerebral palsy notwithstanding, he thinks of Galileo and pauses. Maybe the maverick scientist's only problem is that he is first. Maybe today's junk science will be tomorrow's orthodoxy.

226. Merewood, Chicago Tribune at C3 $\S 6$ (cited in note 209), quoting Dr. Stephen Meyers, director of Maternal-Fetal Medicine at Mt. Sinai Hospital, Chicago, Ill.

227. Stephen A. Myers \& Norbert Gleicher, A Successful Program to Lower Cesarean-Section Rates, 319 New Eng J Med 1511, 1515 (1988).

228. Id.

229. Anthony Z. Roisman, Law And Science: Partners Or Protagonists?, in Symposium III, Immunotoxicology at 105, 132 (cited in note 37).

230. Alan S. Levin, Environmental Illness A Scientific Reality, A Legal Boondoggle, A Potential American Tragedy, in Symposium III. Immunotoxicology at 88 (cited in note 37). 
It is certainly a powerful allusion. Galileo, we may recall, was summoned to trial by the Inquisition and condemned to life imprisonment on "vehement suspicion of heresy." His crime had been to observe the phases of Venus and espouse the Copernican theory. Today we know that Galileo was right and those who thought to judge him were wrong. This is an episode in the history of jurisprudence we do not wish to repeat.

We are not likely to; the situation in American courts is now completely reversed. When Martin Gardner's "hermit scientist" approaches the trough of liability insurance, many an American jurist is still inclined to welcome the new snout, in the hope that there may be a pearl in there among the swine. The maverick scientist on the witness stand is accorded high respect. He is often permitted to testify about theories that he alone espouses, report on observations that he alone has made, based on methods that he alone understands and accepts.

The solitary physician fares even better. Virtually any doctor armed with a medical degree is qualified to testify. Sometimes he will be expected to assert that his opinion has a "reasonable basis," that it is not based on chicken entrails or phases of the moon, but this is not much of a standard. He need not be a recognized authority or specialist. He need not reconcile his opinions with public health statistics of epidemiology. ${ }^{231}$ He need not establish that his diagnostic methods or logical leaps enjoy "general acceptance" among other doctors. Quite the contrary: he may insist that he alone among doctors understands the importance or origins of certain symptoms. He may claim, in short, to be a modern day Galileo, a lonely, misunderstood genius who can see wonders that others neither discern nor understand.

Thus, many judges now assume that in matters testimonial new must surely mean improved, and that one-of-a-kind probably means one-of-thebest. As a New Jersey appellate judge put it in 1990, an expert who believed that PCBs had caused colon cancer "may have been too qualified and advanced in his thinking, based upon his extraordinary expertise. There always has to be a first; someone must always be the innovator." 232 "I suppose that Christopher Columbus could never have been qualified as an expert to render an opinion on circumnavigation and the Wright Brothers would never have been able to testify as experts and give opinions relating to flight because, for much of their day, their views never gained 'general acceptance with the scientific community.' ',233

231. Ferebee v Cheuron Chemical Co., 736 F2d 1529, 1536 (DC Cir), cert denied, 469 US 1062 (1984) ("Products liability law does not preclude recovery until a 'statistically significant' number of people have been injured ....").

232. Rubanick v Witco Chemical Corp., 242 NJ Super 36, 57-58, 576 A2d 4, 15 (1990) (Stern concurring).

233. Id at 58, $576 \mathrm{~A} 2 \mathrm{~d}$ at 15 , citing Windmere, Inc. $v$ International Ins Co., $105 \mathrm{NJ} 373,379,522 \mathrm{~A} 2 \mathrm{~d}$ 405, 408 (1987). 
It scarcely seems to matter that Columbus was in fact mightily confused about circumnavigation, while the Wright brothers' achievement was in fact immediately and widely accepted.

\section{A. Slouching Into Court}

Most lawyers will concede that the scientist ahead of his time is sometimes wrong. But judges (the answer runs) simply must take some risks with leadingedge claims, to keep ahead of complacent scientists in the mainstream. Remember, after all, asbestos, the Ford Pinto, and the Dalkon Shield, Rely tampons, DES, and thalidomide. Real risks, every one of them, first exposed by lawyers and their (at the time) "maverick" experts. Or so many lawyers will maintain.

The history of science records otherwise. The pathbreaking scientific work on asbestos was conducted by Dr. Irving Selikoff in 1962-63; his findings were presented soon thereafter in mainstream scientific publications and symposia. ${ }^{234}$ The lawsuit that launched asbestos litigation was not filed until October 1969,235 and four more years passed before appeals were resolved. The Dalkon Shield's serious problems were recognized by physicians soon after A. H. Robins launched global sales in 1971. Though at that time it lacked formal jurisdiction over medical "devices," the Food and Drug Administration asked Robins to halt sales and Robins complied in June 1974 . The first solid epidemiological indictment of the Dalkon Shield was published by Dr. Nancy Lee of the Centers for Disease Control in 1983. ${ }^{236}$ The serious litigation was then only just getting under way. ${ }^{237}$

In 1968, at almost exactly the same time as Robins executives were planning to launch the Dalkon Shield, Lee Iacocca, then a Ford vice president, initiated design of the Ford Pinto. ${ }^{238}$ A first relevant crashworthiness standard promulgated by the National Highway and Traffic Saftey Administration ("NHTSA") had gone into effect earlier that year; stricter standards would follow in 1975, 1976, and 1977. In 1977, NHTSA also initiated an investigation of Pintos already on the road; in May 1978, it formally concluded that Pintos had serious problems, and a month later, under strong pressure from the agency, Ford initiated a recall. ${ }^{239}$ Where were the lawyers? In February 1978, a California jury returned the landmark, $\$ 127.8$ million verdict in Richard Grimshaw's suit against Ford. In September 1978, an Indiana grand jury indicted Ford on three counts of reckless

234. For example, Irving J. Selikoff, Jacob Churg \& E. Cuyler Hammond, Asbestos Exposure and Neoplasia, $188 \mathrm{~J}$ Am Med Assn 22-26 (April 6, 1964).

235. Borel v Fibreboard Paper Prods., 493 F2d 1076 (5th Cir 1973), cert denied, 419 US 869 (1974).

236. Nancy C. Lee, et al, Type of Intrauterine Device and the Risk of Pelvic Inflammatory Disease, 62 Obstetrics \& Gynecology 1, 1-6 (July 1983).

237. On January 9, 1984, for example, UPI ran an overview story on the Dalkon Shield and pending litigation with the title-absurdly tentative in retrospect-"Contraceptive maker may have to compensate women." United Press International (NEXIS, Jan 9, 1984).

238. See Grimshaw v Ford Motor Co., 119 Cal App 3d 757, 774, 174 Cal Rptr 348, 359 (1981).

239. William H. Jones, Ford Recalls 1.5 Million Small Cars, Washington Post A1 (NEXIS, June 10 , 1978). 
homicide. But it took another two years for the Indiana criminal trial to be resolved-in Ford's favor. ${ }^{240}$ In May 1981, a California court of appeals finally upheld $\$ 3.5$ million of the Grimshaw verdict, ${ }^{241}$ emphasizing in its opinion the Pinto's shortcomings as against NHTSA's 1973 standards. ${ }^{242}$ In May 1982, Richard Grimshaw finally settled his claim against Ford while the case was still under appeal. By this time, Lee Iacocca had left Ford and was president of Chrysler.

Time and again, the scientists and regulatory agencies have been way out ahead of the litigators. The key scientific discoveries on DES were published in The New England Journal of Medicine in 1971.243 Serious litigation developed only after a key opinion was handed down by the California Supreme Court in 1980.244 The swine flu vaccine was distributed in $1976 ;^{245}$ the Centers for Disease Control ("CDC") study linking it to Guillain Barre Syndrome was published in The American Jourmal of Epidemiology in 1979.246 The litigation again developed thereafter. Proctor and Gamble first test-marketed the Rely tampon in 1974. ${ }^{247}$ Toxic Shock Syndrome ("TSS") was first described in The Lancet in November 1978, ${ }^{248}$ first linked (by the CDC) with menstruation in May 1980 and with Rely users in August and September of that same year. ${ }^{249}$ Proctor and Gamble withdrew Rely from the market immediately. The first TSS trial was not even held until 1982 ;250 $^{2}$ the jury found Rely tampons defective but found no breach of warranty and awarded no damages. ${ }^{251}$

A last word is in order on Thalidomide. More than one prominent U.S. lawyer has had the gall to claim Thalidomide as yet another success for the investigative sleuths of the American plaintiffs' bar. ${ }^{252}$ In Europe, some 6,500 children were victims of the drug before its teratogenic properties were confirmed in 1961 by German scientists. Happily, the drug never received FDA approval in the United States.

240. See Joseph P. Kahn, When Bad Management Becomes Criminal, 46 Inc. 73 (March 1987).

241. Grimshaw v Ford, 119 Cal App 3d at 818, 174 Cal Rptr at 388.

242. Id at 775,174 Cal Rptr at 360 .

243. Arthur L. Herbst, Howard Ulfelder \& David C. Poskanzer, Adenocarcinoma of the Vagina: Association of Maternal Stilbestrol Therapy with Tumor Appearance in Young Women, 284 New Eng J Med 878 (April 22, 1971).

244. Sindell v Abbott Laboratories, 26 Cal 3d 588, 163 Cal Rptr 132, 607 P2d 924, cert denied, 449 US 912 (1980) (manufacturers of drug DES could be held liable in class action suit brought by women whose mothers took DES during pregnancy).

245. See In re Swine Flu Immunization Products Liability Litigation v United States, 533 F Supp 567, 57 I72 (D Colo 1980).

246. Lawrence B. Schonberger, et al, Guillain-Barre Syndrome Following Vaccination in the National Influenza Immunization Program, United States, 1976-1977, 110 Am J Epidemiology 105, 112-13 (1979).

247. See Kehm v Proctor E Camble Mfg. Co., 724 F2d 613, 616 (8th Cir 1983).

248. James Todd, et al, Toxic-Shock Syndrome Associated with Phage-Group-1 Staphylococci, 2 Lancet $1116-18$ (Nov 25, 1978).

249. Centers for Disease Control, 29 Morbidity and Mortality Weekly Report 441 (Sept 19, 1980).

250. Lampshire v Proctor $\Xi$ Gamble, 94 FRD 58 (1982).

251. Marcia Anne Mobilia \& Annette MacKay Rossignol, The Role of Epidemiology in Determining Causation in Toxic Shock Syndrome, Jurimetrics J 78, 82-86 (Fall 1983).

252. Debate between Peter Huber \& Stanley M. Chesley, held before the Cincinatti Federalist Society, Sept 14, 1989. 
No doubt plaintiffs' lawyers and their experts have often affirmed sound science in court and secured compensation for many who deserved it. But when they did, they had no need for let-it-all-in rules of scientific evidence; litigation moves at a testudinal pace, and solid science was always well out ahead of the lawyers. Key scientific and engineering investigations were completed and published long before the legal claims were pressed or decided. Almost always, these same discoveries also triggered appropriate reaction by the EPA, NHTSA, the FDA, or the industry itself long before trial lawyers had achieved anything at all.

The one race that the courtroom experts win predictably is the one with no prize at the end for anyone but litigants. Often enough, this kind of race is precipitated quite inadvertently, by a perfectly reputable and serious scientific investigator, who carefully qualifies as tentative and preliminary the novelties he reports. But litigation can instantly transform cautious speculation into Galileo-like pronouncement.

In 1985 , for example, contraceptive lawyers won a spectacular $\$ 5.1$ million verdict against the Ortho Pharmaceutical Corporation,, ${ }^{253}$ largely on the strength of a single study that had very tentatively suggested that spermicides might cause birth defects. ${ }^{254}$ A year after the verdict, however, the several authors of that study spoke out again. One acknowledged that their work "was not corroborated by subsequent studies" and that their "study's definition of exposure to spermicide near the time of conception was grossly inaccurate." 255 Another frankly conceded: "I believe our article should never have been published. In our present litigious environment, the reservations and qualifications written into a published report are often ignored, and the article is used as 'proof of a causal relationship." 256 Two independent physicians from the National Institute of Child Health and Human Development noted that "the overwhelming body of evidence indicates that spermicides are not teratogenic." 257

The legal disaster of the pertussis (whooping cough) vaccine developed in much the same way. The vaccine has virtually ended the 265,000 cases of pertussis and 7,500 pertussis-related deaths recorded in the years before 1949, when the vaccine was first licensed. ${ }^{258}$ A 1984 English study, however, though serious and cautiously phrased in itself, suggested that the vaccine's use (extrapolated to the U.S. population) might be causing twenty-five cases a

253. Wells v Ortho Pharmaceutical Corp., 615 F Supp 262 (ND Ga 1985), aff'd, 788 F2d 741 (11th Cir), reh'g denied en banc, 795 F2d 89 ( 1 lth Cir), cert denied, 479 US 950 (1986).

254. Hershel Jick, et al, Vaginal Spermicides and Congenital Disorders, $245 \mathrm{~J}$ Am Med Assn 1329-32 (April 3, 1981).

255. Richard N. Watkins, Vaginal Spermicides and Congenital Disorders: The Validity of a Study, $256 \mathrm{~J}$ Am Med Assn 3095 (Dec 12, 1986) (letter); Lewis Holmes, Vaginal Spermicides and Congenital Disorders: The Validity of a Study, $256 \mathrm{~J}$ Am Med Assn 3096 (Dec 12, 1986) (in reply to Watkins's letter).

256. Holmes, $256 \mathrm{~J}$ Am Med Ass'n at 3096 (cited in note 255).

257. James Mills \& Duane Alexander, Occasional Notes: Teratogens and "Litogens", 315 New England J Med 1234, 1235 (Nov 6, 1986).

258. See Graham $v$ Wyeth Laboratories, 666 F Supp 1483, 1485 (D Kan 1987), rev'd, 906 F2d 1399 (1990). 
year of serious brain damage. ${ }^{259}$ American lawyers responded with an avalanche of litigation, ${ }^{260}$ blaming the vaccine for permanent brain damage, unexplained coma, Reye's syndrome, epilepsy, sudden infant death, and countless other afflictions. Horrified pharmaceutical companies bailed out, and at one point it appeared that the last American manufacturer of the product would be leaving the market. ${ }^{261}$ More solid scientific evidence then slowly accumulated. ${ }^{262}$ In March 1990, a report of a large study of 38,171 children and 107,154 immunizations concluded that the vaccine had caused no serious neurological complications of any kind and no deaths. ${ }^{263}$ "It is time for the myth of pertussis vaccine encephalopathy to end," declared an editorial in the Journal of the American Medical Association. "We need to end this national nonsense."264 By this time, however, Congress has enacted the National Childhood Vaccine Act, which now issues checks for children lucky enough to have been vaccinated shortly before they fall seriously ill from other causes.

Now and again a scientific iconoclast, even one based at a prestigious institution, is simply less cautious than he should be, and more openly confident about his solitary status. An example is Dr. Joseph A. Bellanti, a respected physician who took off on an idiosyncratic crusade. Three trial judges in Wisconsin successively rejected Bellanti's testimony in 1981,265 and then twice in $1982,{ }^{266}$ that the swine flu vaccine caused rheumatoid arthritis, polymyalgia rheumatica, and Guillain Barre Syndrome ten months after vaccination. A South Dakota judge ruled against Bellanti in 1983 on links between the vaccine and brain-stem stroke. ${ }^{267}$ In 1984, however, Bellanti convinced a federal court of appeals that the vaccine caused "serum sickness," and so helped secure an award of $\$ 212,802 .{ }^{268}$ In 1984, despite Bellanti's testimony, a Michigan judge ruled that the vaccine did not cause muscular

259. See Alan Hinmon \& Jeffrey Koplan, Pertussis and Pertussis Vaccine: Reanalysis of Benefits, Risks, and Costs, $251 \mathrm{~J}$ Am Med Assn 3109 (June 15, 1984).

260. See Harris L. Coulter \& Barbara Lee Fisher, DPT, $A$ Shot in the Dark (Harcourt Brace Jovanovich, 1984); Stephen Engelberg, Vaccine: Assessing Risks and Benefils, NY Times CI col 4 (Dec $19,1984)$.

261. See Christine Russell, Firm Ceases Making Vaccine, Washington Post Al col 1 (June 19, 1984); The Cost of Ignoring Vaccine Victims, NY Times A 18 col 1 (Oct 15, 1984) (editorial); Philip Boffey, Vaccine Liability Threatens Supplies, NY Times Cl col I (June 26, 1984); Stephen Engelberg, Official Explains Gaffe on Vaccine Shortage, NY Times A21 col 1 (Dec 19, 1984); Stephen Engelberg, Vaccine Company to Ease Shortage, NY Times 10 col 6 (Dec 15, 1984).

262. For example, Alexander Walker, et al, Neurologic Events Following Diphtheria-Tetanus-Pertussis Immunization, $81 \mathrm{~J}$ Pediatrics 345-49 (1988); W. Donald Shields, et al, Relationship of Pertussis Immunization to the Onset of Neurologic Disorders: A Retrospective Epidemiologic Study, $113 \mathrm{~J}$ Pediatrics 801 (Nov 1988).

263. Marie Griffin, et al, Risk of Seizures and Encephalopathy after Immunization with the DiptheriaTetanus-Pertussis Vaccine, $263 \mathrm{~J}$ Am Med Ass'n 1641 (March 1990). See also Gina Kolata, Whooping Cough Vaccine Found Not to be Linked to Brain Damage, NY Times A19 col 1 (March 23, 1990).

264. James Cherry, "Pertussis Vaccine Encephalopathy": It Is Time to Recognize It as the Myth That It Is, 263 J Am Med Assn 1679, 1680 (March 1990).

265. See Gicas v United States, 508 F Supp 217 (ED Wis 1981).

266. See Latinovich $v$ United States, 537 F Supp 671, 676-77 (ED Wis 1982); Kubs v United States, 537 F Supp 560, 563 (ED Wis 1982).

267. Zeck v United States, 559 F Supp 1345, 1349-50 (D SD 1983).

268. Petty $v$ United States, 740 F2d 1428, 1432.33 (8th Cir 1984). 
cramps and "flexion contractures."269 In 1989, another judge was persuaded by Bellanti that the vaccine did cause fatal dermatomyositis, but an appellate court reversed. ${ }^{270}$ Bellanti is a respected and undoubtedly sincere physician, but as his long pilgrimage through courts richly illustrates, a single sincere physician who has latched on to maverick views can make quite a career for himself on the litigation circuit.

So without doubt, the lawyers and the idiosyncratic experts who backed them have been way out ahead on clinical ecology, sudden acceleration, and the teratogenic effects of Bendectin. Of course they were out ahead. To outof-court, mainstream scientists, the factual claims looked dubious all along. So the hired testifiers took a big lead, and declared many a victory against cruise controls, cerebral palsy, and cancer. The real scientists arrived later on only to establish that nothing had really been improved at all.

\section{B. Goodbye Galileo}

No one would suggest that the iconoclast, maverick, crank, or congenital rebel is invariably wrong; historical counter-examples are too familiar. Sir Percivall Pott, a respected English surgeon, noticed in 1775 that chimney sweeps suffered disproportionately from cancer of the scrotum. So began the modern science of occupational disease. Two decades later one of his contemporaries would notice that dairy maids suffered from another occupational illness-cowpox-which then seemed to protect them from smallpox. Thus Edward Jenner discovered the "cow treatment," better known today as "vaccination," after the Latin vacca, or cow. In 1850, the great Hungarian clinician Ignaz Philipp Semmelweis discovered peculiar effects of still another occupational toxin-chlorinated lime. The patients of physicians whose hands were regularly exposed to this corrosive chemical did not die of puerperal fever. Thus originated modern notions of antisepsis.

One must never forget, however, that solitary clinicians also gave us the erroneous theories of traumatically induced cancer, cerebral palsy, and countless other spurious connections. Occasional triumphs notwithstanding, the isolated clinician is unusually vulnerable to the snares of junk science. He is always at risk of being fooled by the unscientific impressions of his own patient, who will too clearly remember (for example) the on-the-job trauma that preceded the development of cancer. He is especially likely to slip into post-hoc reasoning, because he always sees the accident or disease first, then scouts around for causes. "Because toads appear after a rain it is not necessary to assume that it has rained toads," an exasperated authority on cancer would point out in 1947, "yet this form of reasoning fills our medical testimony concerning trauma."”271

269. Carter v United States, 593 F Supp 505, 514 (WD Mich 1984).

270. Novak v United States, 865 F2d 718 (6th Cir 1989).

271. Fred W. Stewart, Occupational and Post-Traumatic Cancer, 23 Bull NY Academy Med 145 (1947). 
Opportunities for toad-raining reasoning are everywhere. With 400,000 new cancers diagnosed every year, and much larger numbers of bangs, blows, and broken limbs, some number of doubly unlucky people will inevitably suffer a blow first, then a cancer. When 100,000 babies are born with birth defects every year, and 100,000 pregnant women take Bendectin, there will be considerable overlap, even if Bendectin is pure sugar. But to understand such statistics, you either have to survey all three million pregnancies, or you must be very careful in your selection of a smaller group for study. Clinical work, however, is the medicine of small groups selected unsystematically. The clinician is thus in constant peril of basing grave conclusions on meaningless statistical fluctuations.

The post-hoc fallacy is all the more likely when there is cause-but operating the other way around. One clinician examines the patient's rockbruised leg and finds cancer. Carcinogenic rocks, the clinician infers. Another witnesses a traumatic birth and then finds cerebral palsy. Traumatic brain damage, the clinician infers. In fact, it is probably just the other way around: the cancer in some sense caused the trauma; the cerebral palsy precipitated a traumatic delivery. This is the "traumatic determinism" Ewing discussed in 1935. A brain tumor more likely causes dizziness, which causes a fall and a concussion, which causes discovery of the tumor. In 1897, Freud correctly suggested that a similar diagnostic fallacy might well be involved with cerebral palsy. ${ }^{272}$ The clinician is always in danger of putting the causal cart before the effectual horse, because clinical practice emphasizes the here and now. Only rigorous medical science can sort out the before and after.

The history of how that science evolved is indeed a history of how the individual iconoclast has been steadily displaced by the community of scientists. Until the late seventeenth century, as historian James Burke describes, a medical career "flourished or foundered according to the relationship the doctor managed to strike up at the bedside."273 The doctor would emphasize his "heroic and secret" insights into disease and its cure. Each individual's illness was thought to be a unique condition. Each doctor "would claim that all other doctors were quacks and their remedies ill-advised and dangerous." 274 Remedies were correspondingly quirky. The patient's own view of what kind of treatment he needed was often the main basis for recommending a cure.

In 1800, the French surgeon Xavier Bichat published his Treatise on Membranes, ${ }^{275}$ showing disease to be a specific phenomenon peculiar to certain lesions or tissues. It had been thought prior to Bichat's work that every disease could exhibit every symptom; after publication, however, doctors began to recognize that disease presents a specific and concrete target that

272. Freud, Infantile Cerebral Paralysis at 142 (cited in note 196).

273. James Burke, The Day the Universe Changed 197 (Little Brown, 1985). My discussion here and later on the evolution of medical science draws on id at 195-237.

274. Id at 197.

275. Xavier Bichat, Treatise on Membranes (1880), discussed in Burke, The Day the Universe Changed at 207-08 (cited in note 273 ). 
transcends individual patients. The physician, who could learn about disease from many different patients, took control.

As medicine raised its sights from the idiosyncratic and particular to the regular and general, it converged with statistics, a new branch of mathematics that was evolving during the same period. In 1662, the Englishman John Graunt examined fifty years of London birth and death records and discovered that numbers revealed much about disease that is not inferable from individual patients. ${ }^{276}$ By the early $1700 \mathrm{~s}$, insurance companies were using statistics to set premiums. In 1795 the foremost French physicist, Pierre-Simon Laplace, began to lecture on the calculus of probability. Laplace would eventually show how statistics could systematically improve observation, establish the reliability of experimental results, and reveal hidden regularities; he would then derive the mathematical rules for extrapolating from small numbers to large, and formalize the important concept of a statistically meaningful result. ${ }^{277}$

As doctors grasped the power of the new mathematics, the center of medical learning shifted to the hospital, where patients could be studied in still larger numbers. The center of expertise now resided not with the individual physician but his college, his peers, his network of associates. By the 1820s, doctors in Paris had developed an entirely new view of disease and treatment, one much closer to the modern model. As Burke recounts, "[b]edside secrets gave way to a desire among doctors to share techniques and information."'278 Medical journals proliferated.

When cholera struck Europe in 1829, the hospitals were replaced as study cite cities. Desperate to contain the scourge, the British Parliament established a General Register Office to gather data. William Farr, appointed controller, believed firmly in the order and regularity of disease. "[M]ortality and sickness . . . are constant in the same circumstances," he wrote, "varying as the causes favourable or unfavourable to health preponderate." 279 He set out to conquer cholera with a radically new medical instrument: the biometer. The biometer was pencil and paper-a life-table that insurance company actuaries had been using for years. Farr systematically analyzed who was dying and where.

The most important things he discovered were negative. Wealth did not protect you from cholera. Nor occupation, nor residential proximity to the sea. What mattered was how high you lived above the Thames. Farr concluded that cholera was caused by the river's awesome stench. The last step of his analysis was wrong, but all the others were right. Another English physician, John Snow, made the right connection in 1853.280 The key was not dirty air but dirty water; the London sewers emptied into the Thames, so the

\footnotetext{
276. Burke, The Day the Universe Changed at 209 (cited in note 273).

277. Id at $210-11$.

278. Id at 213 .

279. Id at 227; see also John M. Eyler, Victorian Social Medicine: The Ideas and Methods of William Farr 9 (Johns Hopkins U Press, 1979).

280. Burke, The Day the Universe Changed at 230 (cited in note 273).
} 
further down-sewer you lived, the more likely you were to drink foul water. A few years later Parliament passed legislation to rebuild the sewers, and cholera disappeared from the city forever. No physician, and certainly no patient, yet understood precisely why.

That understanding would evolve soon enough, however, from Louis Pasteur's 1857 study of fermentation and his theory of "airborne germs."281 Within a decade, a surgeon in Glasgow who learned of Pasteur's work began to clean wounds after surgery with carbolic. So it was that Dr. Joseph Lister, a contemporary of Semmelweis, laid another keystone in the foundation of modern antisepsis. By 1876, a German general practitioner, Robert Koch, had cultured the anthrax bacillus; soon after he would isolate the great devastating tubercle bacillus.

Thereafter, it would be in the study of the many, and invariably by the many, that medicine discovered the causes of polio and pertussis, tuberculosis, lung cancer, mesothelioma, and countless other afflictions. Epidemiology supplied detailed insight into hepatitis, Lassa fever, Legionnaires' disease, and TSS before their causative agents were identified. It is epidemiology, the study of the many, that systematically converts clinical observation into science. Time and again, the epidemiologists produced results decades, sometimes centuries, before others came close. ${ }^{282}$

It was thus that medicine was transformed from black art to science, from study of the idiosyncratic and particular to understanding of the regular and general. It would of course take years for medical practice to catch up on all fronts with medical science, and some clinicians still disdain medical science to this day. At each step, however, medical science distanced itself from individual eccentricity on both sides of the stethoscope. The main difference between the clinician who cures, and the clinician who quacks, has turned out to be the difference between the hermit and the scientist who is an integral part of a community of learning. For the one, medicine is shaped by an endless series of peculiar and individual cases; for the other, by broad perspective and consensus conclusions. One espouses truths as evanescent as the individual patient and doctor, the other truths that transcend individuals.

It is a difference that, with minor variations, has defined the origins of all sciences, not just medicine. In 1660, there was established the "Colledge for the Promoting of Physico-Mathematicall Experimentall Learning,"'283 which became London's Royal Society. Since that time, the rise of all Western science has been marked by the decline of the solitary scientist. It is true that when new fields open up today, as in the 1700 s, only a very few initially know or believe. This only proves that group enterprise begins with something smaller than a group. Modern science is rooted not in any particular discovery, but in the development of formalized collegiality among scientists.

\footnotetext{
281. Id at 234 .

282. See Richard Peto. The Preventability of Cancer, in M. P. Vessey \& Muir Gray, eds, Cancer Risks and Prevention 1, 14 (Oxford U Press, 1985).

283. See T. E. Allibone, The Royal Society and Its Dining Clubs 1 (Pergamon Press, 1976).
} 
And this remains the essential (and most readily ascertainable) difference between real science and the other kind. The hermit scientist, as Gardner described, operates "quite apart from the cooperative process of communication and testing that goes on constantly within every branch of science."284 Trial lawyers should be able to recognize him easily enough, for they sometimes have occasion to sue him for his malpractice. Without good science to back him, the clinician is just an enthusiast armed with a sharp knife.

So who now stands on the shoulders of the giants of epidemiology, PierreSimon Laplace, William Farr, and John Snow? In court, the answer often seems to be this or that peripatetic testifier, "a real-life Quincy," proud that he works with "live people instead of stiffs." 285 A court that welcomes such witnesses is one that still views medicine through eighteenth-century eyes, one that thinks of science as something peculiar to the individual chemist, toxicologist, or engineer, divorced from larger patterns of experience.

Such a court ignores the group consensus critical to science and exalts the individual. It unconditionally favors the expert witness who is most confident, vehement, and personally assertive-which is to say, the one least cautious, reticent, and scientific. Perhaps spermicides do not cause birth defects. Not very often, that is. But who really knows with absolute certainty that a spermicide did not, on just one occasion in all of history, cause injury to unborn Katie Wells? Same thing for Bendectin and Mary Oxendine, or for delivery trauma and Matthew V. Rutherford. Who's to say? Why the individual doctor, of course. Medicine is as singular as disease. Each patient, each injury, each illness is really unique, so diagnosis must be too. It all comes down to personal judgment. Or so says the eighteenth-century doctor, on the payroll of the twentieth-century lawyer.

It is as if Graunt, Laplace, Farr, and Snow, had taught us nothing at all. Does trauma cause cancer? Does the electronic fetal monitor prevent cerebral palsy? Do trace pollutants cause chemical AIDS? These are not questions for the Hollywood Squares, or for their equally colorful counterparts at the fringes of the medical profession. These are-or should be-questions of science, to be answered using the methods of Farr and the mathematics of Laplace, questions that have culminated in rigorous statistical investigations of trauma and cerebral palsy, Bendectin and clinical ecology.

Modern science is a group endeavor. It is a process, not a result-a process of replication and verification, a search for consensus. A scientific fact is not one known to the individual in his heart, but one recognized by the community, in its journals and symposia. Science is the eternal quest for objectivity, for what we see together, though from different vantage points, in our waking hours. It is not what we see alone, in our dreams. Science not

284. Gardner, Science: Good, Bad and Bogus at 5 (cited in note 2).

285. See Marcella S. Kreiter, Occupational Medicine Specialist, United Press International (NEXIS, April 5, 1982), quoting Bertram Carnow. 
backed by a scientific community is not science at all. The hermit scientist is not fundamentally different from a copy editor at the National Enquirer.

\section{Singular Science}

Modern science is not a solitary undertaking. Litigation is. And that fundamental difference-the difference between the relentless collegiality of science and the hermetic isolation of a trial-is what makes it so very difficult to maintain good science in court. Real science is the study of facts that are regular, of things that recur in patterns; a courtroom trial is quintessentially singular. Science depends on placing facts in an orderly context; a trial frames facts in isolation. Good science transcends the here and now, the individual and idiosyncratic, the single laboratory, the single nation, the single planet, even the single galaxy; a trial typically examines a singular datum and demands that scientific truths be rediscovered every time anew. Scientific facts emerge from many isolated observations, as data are accumulated, vetted for error, tested for significance, correlated, regressed, and reanalyzed; trials are conducted retail. Good science is open, collegial, and cumulative; the courtroom setting is discrete, insular, and closed-a one-shot decision. It is not merely possible that bad science will emerge in this kind of environment, it is likely. Unless rules of evidence are carefully maintained, courtroom scientists will soon drift away from the science they purport to represent.

Our rules of evidence have not been maintained, however. To the contrary, they have been systematically dismantled. We have abandoned Frye. We defer more readily than ever to the hermit clinician. We have thus transferred authority from the profession to its individual members. The expert no longer testifies about what is accepted as valid in the mainstream of his profession, he testifies about what he personally believes. Often enough, even in these degenerate legal times, he will still be a reputable and careful professional, conscientiously answering the wrong questions in front of the wrong audience. Too often, however, he will be shouldered aside by a more ambitious-and less scrupulous-colleague who, under the new standards, may be as idiosyncratic and whimsical as he chooses. And so our courts come to welcome and enrich the all manner of cranks and eccentrics from the fringes of science.

Severing the link between mainstream science and the individual scientist is all but certain to produce bad science. The junk scientist, as Martin Gardner describes, is always isolated from his mainstream colleagues. "[He] stands entirely outside the closely integrated channels through which new ideas are introduced and evaluated. . . . $[\mathrm{H}] \mathrm{e}$ finds himself excluded from the journals and societies . . ."286 He loves the neologism, a word filled with meaning for him, but "Jabberwocky to everyone else." 287 He denounces "the prejudice of established scientific groups against new ideas," and claims close

286. Gardner, Fads and Fallacies at 11 (cited in note 8).

287. Id at 13-14. 
kinship with the maverick geniuses of yesteryear. ${ }^{288}$ "He likens himself to Bruno, Galileo, Copernicus, Pasteur, and other great men who were unjustly persecuted for their heresies." "[H]e will attribute this persecution to a scientific masonry, unwilling to admit into its inner sanctums anyone who has not gone through the proper initiation rituals." 289 And under modern rules of evidence, he will be welcome in court.

Not everywhere, of course. Many good judges still hold the line, invoking Frye, emphasizing epidemiology, demanding scientific publication and peer review as a basis for expert testimony. For every court that does so, however, another remains quite comfortable with the junk science of hermits. The Bendectin trials and appeals in D.C. federal courts were matched, motion for motion, witness for witness, with trials and appeals in the district's local courts, and while good science was affirmed in the former, junk eventually prevailed in the latter. Epidemiology backed by the CDC persuaded some courts hearing swine flu cases; Joseph Bellanti persuaded others. ${ }^{290}$ Radiation experts dismissed as far out of the mainstream by one federal judge, ${ }^{291}$ convince another. ${ }^{292}$

Most judges and juries, most of the time, may call the science right. But the minority who call it wrong can have an impact far out of proportion to their numbers. With Bendectin, the first thousand claims in the giant class are finally resolved in line with mainstream science, though not before Merrell is impelled to offer $\$ 120$ million to buy its way out of the legal quagmire. ${ }^{293}$ Merrell ultimately wins most of the individual trials too. But David Mekdeci's jury returns a sympathy verdict of $\$ 20,000,{ }^{294}$ and others return awards of $\$ 750,000,295 \$ 1.16$ million, ${ }^{296}$ and then $\$ 95$ million. ${ }^{297}$ The median jury verdict is thus $\$ 0$, but the average jury award is close to $\$ 100,000$. Litigation over polio vaccines yields a string of outright victories for defendants, an occasional modest jury award $\left(\$ 200,000\right.$ in 1974 , for example $\left.{ }^{298}\right)$, then a June 1984 blockbuster- $\$ 2$ million in compensatory damages, $\$ 8$ million in

\footnotetext{
288. Id at 9 .

289. Id at 13 .

290. Compare Sulesky v United States, 545 F Supp 426 (SD W Va 1982) with Petty, 740 F2d 1428 (8th Cir 1984).

291. Johnston v United States, 597 F Supp 374 (D Kan 1984), cert denied, 484 US 1004 (1988).

292. Allen v United States, 588 F Supp 247, 419-23 (D Utah 1984), rev'd on other grounds, 816 F2d 1417 (10th Cir 1987), cert denied, 484 US 1004 (1988).

293. Drug Company Offers $\$ 120$ Million in Settlement, NY Times $\S 1$ at 21 (July 15, 1984).

294. See Mekdeci v Merrell Dow, 711 F2d 1510 (1 lth Cir 1983); Morton Mintz, Drug for "Morning Sickness" is Suspected in Birth Defects, Washington Post A7 (Feb 11, 1980). The award was of course overturned.

295. See Peter Perl, $\$ 750,000$ Judgment Found Against Maker of Bendectin, Washington Post Al (May $28,1983)$..

296. Richardson v Richardson-Merrell, Inc, 649 F Supp 799, 801 (D DC 1986).

297. Morton Mintz, Deformed D.C. Boy Awarded \$95 Million; Bendectin Maker Penalized, Washington Post Al (July 15, 1987); Ealy v Richardson-Merrell, Inc., 1987 WL 18743 (D DC), reversed by 897 F2d 1159 (DC Cir 1990)

298. Ryes $v$ Wyeth Laboratories, 498 F2d 1264 (5th Cir 1974).
} 
punitives. ${ }^{299}$ After appeals, many of these junk-science verdicts are overturned. Quite a few survive even that tier of review, however, and litigation marches on, with a new bank-breaking verdict always possible just over the horizon. No matter how many times an iconoclastic expert witness may be repudiated in court, he is always free to testify again somewhere else.

Trials are not connected. Everyone is entitled to at least one day in court, so the same question about Bendectin, the Audi, or clinical ecology can be litigated again and again. The legal rule of "collateral estoppel," which sometimes bars a defendant from relitigating an issue it has already lost, does not stop a plaintiff from relitigating an issue that the defendant has won against other plaintiffs. Class actions have likewise failed to promote consistency. As Merrell, Audi, Monsanto, and others have learned, huge class actions often promote nothing but extortion, squeezing expensive settlement from bottom-of-the-barrel science. Class actions round up claimants, but they do not help much in rounding up scientific wisdom.

So the scientific facts are perpetually in play; the law itself has no anchor. In the worst cases, courts drift through the degenerative sequence described by historian Jerome Ravetz ${ }^{300}$ and thereafter elaborated by W. C. Clark. ${ }^{301}$ When immature sciences are applied to social problems, tentative outlooks are often suppressed, and views are quickly polarized. If conditions are ripe, a "great confidence game" replaces serious science. ${ }^{302}$ The upshot is often "unnecessary public alarm, unjustified and ineffective regulations, and an unwillingness to undertake the risk-taking ventures necessary for coping with the unknown." 303 Recognition and money flow "to those making the first, loudest, and most frightening noises." 304 The careful skeptic is rewarded with "accusations of corruption, cowardice, or insensitivity." 305 There will be "an accretion of cranks and congenital rebels whose reforming zeal is not matched by their scientific skill."'306

\section{Galileo and Velikovsky}

The time has come for jurists to make their final peace with Galileo. His story is familiar-too familiar. Its lessons have been learned-too well.

Let us concede, one last time, that Galileo was a great scientist, and that he was persecuted for being right. Let us acknowledge, one last time, the other Galileos too. Yes, contemporaries scoffed at Pasteur's germ theory and at Semmelweiss's insistence that sterilized hands made for healthier obstetrics.

\footnotetext{
299. The verdict was overturned in a 4-3 vote by the Kansas Supreme Court. Johnson $v$ American Cyanamid Company, 239 Kan 279, 718 P2d 1318 (1986).

300. Jerome R. Ravetz, Scientific Knowledge and Its Social iroblems (Oxford U Press, 1971)

301. William C. Clark, Witches, Floods, and Wonder Drugs: Historical Perspectives on Risk Management (Intl Inst Applied Systems Analysis, March 1981) (RR-81-3).

302. Ravetz, Scientific Knowledge and Its Social Problems at 427 (cited in note 300).

303. Clark, Witches, Floods, and Wonder Drugs at 306 (cited in note 301 ).

304. Id.

305. Id.

306. Ravetz, Scientific Knowledge and Its Social Problems at 427 (cited in note 300).
} 
Yes, eighteenth-century astronomers stubbornly refused to believe that stones fell from the sky. Yes, Darwin's theory was dismissed initially by physicists who calculated (correctly) that ordinary combustion could never have kept the sun burning over the Darwinian millennia. Yes, Ernest Rutherford's early theory on the radioactive transmutation of elements was attacked by those who thought it sounded too much like alchemy. Yes, as Gardner reminds us, even a layman occasionally makes an "astonishing scientific" guess. ${ }^{307}$ In Gulliver's Travels, astronomers of Laputa discover that Mars has two satellites and observe the unlikely fact (unparalleled elsewhere in the solar system) that one of the moons rises in the west and sets in the east. Every detail will in fact be confirmed-one hundred and fifty six years after Jonathon Swift first wrote them down-when sufficiently powerful telescopes are finally developed. "The pseudoscientist," Gardner observes, "never tires reminding his readers of these cases." 308

How do serious scientists respond? Modern science is a far cry from science centuries ago. The Renaissance scientists lacked any cohesive social structure or professional journals; their relative isolation is irrelevant today. Galilec had limited opportunity to belong to a larger community of scientists, though one should not forget that Galileo's heresy was to agree with Copernicus. It is only in this century that medicine has finally become a reasonably rigorous scientific discipline. It proves nothing to dredge up ancient examples of correct views that were at first unpopular in the days of scientific prehistory. Today, as Gardner pointed out, "[ $t]$ he prevailing spirit among scientists, outside of totalitarian countries, is one of eagerness for fresh ideas. ... If anything, scientific journals err on the side of permitting questionable theses to be published, so they may be discussed and checked in the hope of finding something of value." 309 Lewis and Clark had no choice but to be solitary explorers in America, but today it is quite possible to live in a city.

Yes, orthodoxies do become established in science and medicine, and then can prove difficult to change. Galileo himself became part of the orthodoxy, and would not believe that the moon caused tides, or that planets moved in ellipses as Kepler maintained. Einstein never was reconciled to quantum mechanics. Science outside the courtroom, however, requires no gavel and issues no final judgment. The great mind of a Galileo or an Einstein loses its suppleness, but other fresh young minds follow, just as these great scientists would surely have wished.

Some of those fresh young minds will do even better, and some much worse. The Galileo of our century, according his once numerous and passionate admirers, was Dr. Immanuel Velikovsky, whose Worlds in Collision ${ }^{310}$

307. Gardner, Fads and Fallacies at 30 (cited in note 8).

308. Id at 9 .

309. Id.

310. Immanuel Velikovsky, Worlds in Collision (Doubleday, 1950). 
was published in 1950, three centuries after the Starry Messenger. ${ }^{311}$ Velikovsky's was, as it happens, another book about Venus, packed with facts, references, footnotes, and quotations. A giant comet, claimed Velikovsky, had erupted from Jupiter and twice passed close to the earth. It was briefly captured by Mars, then settled into solar orbit as the planet Venus. In its first encounter with the earth, it caused the earth to stop spinning, which caused the Red Sea to divide at a highly convenient moment for certain refugees from Egypt. In its second, it supplied atmospherics suitable to the delivery of ten influential commandments on Mount Sinai.

Rank poppycock? When Velikovsky's book was published, an astonishing number of serious reviewers thought otherwise. Velikovsky acquired a large following. His critics from mainstream science could hardly decide which was more ridiculous-his theory, or the fact that so many from outside the scientific community embraced it. Velikovsky coined the term "collective scotoma" (blind spot) to describe the reactions of his opponents, and called on all fairminded people to remember Galileo.

Velikovsky's theories have never made it to court, but Galileo's, as we are constantly reminded, did. Many judges are still trying to atone for that one trial. With few new Galileos at hand, they have regularly made their amends to the Velikovskys instead.

The odds weigh crushingly in the Velikovskys' favor. For every Galileo, there are countless Velikovskys. For every maverick like Pasteur or Semmelweiss, there are thousands of mavericks like Harlan Page Hubbard, the notorious nineteenth century peddler of patent medicines. Yes, there was once a Galileo. There was also once a Rene Blondlot, discoverer of "N" rays; Uri Geller, bender of spoons; and Jose Pedro de Freitas ("Ze Arigo"), a quack physician and "Surgeon of the Rusty Knife." 312 There were also countless peddlers of Krebiozen, Laetrile, Galvanic belt batteries, and radium-spiked Radiothor, the Perrier water of the 1920s.

The existence of these multitudes of quacks does not disprove the existence of Galileo, Semmelweiss, or Pasteur, of course. But a judge determined to ground decisions on accurate scientific facts may nevertheless proceed quite safely on the assumption that the witness who behaves like a crank most likely is a crank. The odds weigh enormously against the second coming of Galileo in court next Tuesday. Velikovsky is a much more likely prospect.

311. See Galileo, Starry Messenger: The Best of Galileo (St. Martin's Press, 1979). The Original was published in 1610.

312. See Fuller, Arigo: Surgeon of the Rusty Knife (cited in note 2). 
